\title{
OPEN The multilevel organismal diversity approach deciphers difficult to distinguish nudibranch species complex
}

\author{
Tatiana A. Korshunova ${ }^{1}$, Floor M. F. Driessen ${ }^{2,3}$, Bernard E. Picton ${ }^{4,5}$ \& \\ Alexander V. Martynov ${ }^{6 \bowtie}$
}

Species identification is a key procedure for broad-scoped ecological, phylogeographic and evolutionary studies. However, to perform a taxonomic study in the molecular era is a complicated task that has many pitfalls. In the present study we use particular examples of common but difficult to distinguish European species within the genus of Polycera (Nudibranchia, Mollusca) to discuss the general issues of the "cryptic species" problem that has broad biological and interdisciplinary importance and can significantly impede ecological, evolutionary, and other biodiversity-related research. The largest dataset of molecular and morphological information for European nudibranchs ever applied encompasses a wide geographical area and shapes a robust framework in this study. Four species are recognized in the species complex, including a new one. It is shown that a lack of appropriate taxonomic analysis led recently to considerable errors in species identity assessment of this complex. Chromatic polymorphism for each species is mapped in a periodic-like framework and combined with statistical analysis of the diagnostic features that considerably facilitates identification of particular species in the complex for biologists and practitioners. The present study evidently shows that "cryptic" and "non-cryptic" components are present within the same species. Therefore, this species complex is well suited for the exploring and testing of general biological problems. One of the main conclusions of this study is that division of biological diversity into "cryptic" and "non-cryptic" components is counterproductive. We propose that the central biological phenomenon of a species can instead be universally designated as multilevel organismal diversity thereby provide a practical set of methods for its investigation.

The species concept is a central biological problem ${ }^{1-4}$. Polymorphism became a key notion for a species concept in the mid-twentieth century ${ }^{5,6}$. The problem of a hidden species (when among polymorphic lineages several difficult-to-distinguish but separate species do exist) had already emerged in the pre-molecular phylogenetic era ${ }^{7}$. When application of molecular data became a routine, any potentially hidden lineages were labelled as "cryptic species". Recently several studies independently showed that this counterproductively disrupts organismal diversity into "cryptic" and "non-cryptic" species ${ }^{9-12}$.

Particularly, to attempt to make a distinction between 'non-cryptic species' and 'cryptic/sibling' species we need a number of intermediate terms, which could grow indefinitely ${ }^{12}$. However, despite that, there are continuous recent attempts to putatively distinguish the terms "cryptic" and "non-cryptic" species, commonly with the presentation of some morphological distinguishing characters that, by definition, mean that the newly separated species cannot be considered as "cryptic"13-15. Hidden diversity therefore is an important problem, especially in the context of the polymorphism ${ }^{16,17}$, which can appear as a parallel-like pattern of characters in two or more closely related species ${ }^{18,19}$. Because within already fine-scale delineated species, it is still possible to uncover more diversity $^{12}$, the commonest European nudibranchs Polycera are investigated in this study in order to further

\footnotetext{
${ }^{1}$ Koltzov Institute of Developmental Biology RAS, 26 Vavilova Str., 119334 Moscow, Russia. ${ }^{2}$ Bureau Waardenburg BV, Aquatic Ecology, Varkensmarkt 9, 4101 CK Culemborg, The Netherlands. ${ }^{3}$ Royal Netherlands Institute for Sea Research (NIOZ), PO Box 59, 1790 AB Den Burg, The Netherlands. ${ }^{4}$ National Museums Northern Ireland, Holywood, Northern Ireland BT18 0EU, UK. ${ }^{5}$ Queen's University, Belfast, Northern Ireland, UK. ${ }^{6}$ Zoological Museum, Moscow State University, Bolshaya Nikitskaya Str. 6, 125009 Moscow, Russia. ${ }^{\square}$ email: martynov@ zmmu.msu.ru
} 
test the reliability of the currently widely discussed "cryptic species" concept. It was specially highlighted in a recent study that the "cryptic species problem" represents a significant importance for the most general species problem ${ }^{20}$ and therefore needs a further detailed exploration.

The species of the genus Polycera are also important for broad-scoped evolutionary and ecological studies, in environmental monitoring, conservation, and are well known to the researchers from various fields and practitioners ${ }^{21-25}$. Particularly, Polycera species became the focus of a study with broad interdisciplinary importance of evolution of the warning colouration ${ }^{26}$. Furthermore, a Polycera species already became an indicator of global warming since it is among few species of European nudibranch which was recently found in the Arctic Barents Sea, but importantly, it was never indicated in historical records for this area ${ }^{27}$. Climate changes are among key modern challenges for protection of the world biodiversity ${ }^{28}$. Therefore this species complex is very well suited for the broad-scaled exploring and testing of many biological problems, including the key cryptic species problem because on one hand this is a very common marine organism which inhabits the whole European region, but on the other hand the species within this complex exhibit substantial polymorphism, which is crucial for study of the general species problem.

In the present study the largest molecular dataset ever available for European nudibranchs at species level is used (in total ca. 200 specimens). The present dataset encompasses a broad area geographically from the subarctic regions of Northern Europe to the Mediterranean Sea in the south and includes data from several European countries and is comprehensive in coverage of morphological, molecular and geographic parameters. It allowed us to exhaustively investigate potential "hidden lineages" within a given species complex and align it with the fine-scale morphological characters. This study also considerably illuminates the problem where an immense external polymorphism is nevertheless restrained by the presence of internal well-diagnosable characters ${ }^{29}$. Ideally, however, a species can be distinguished and diagnosed using external features. This is especially important for quick identification in the field during ecological monitoring. The amount of molecular data presented here further allows mapping of the big range of the polychromatic diversity into several periodically arranged chromatic variants. Afterwards, using statistical methods, the range of variability of the key diagnostic characters are checked inside of these chromatic variants. Thus, a broad integration of molecular and morphological data as well as phylogenetic, phylogeographical and ecological patterns, and statistical analysis will be used in the present study. Application of this approach enables the presentation of diagnosable taxonomic units (important for broad-scoped ecological, phylogeographic and evolutionary studies) in a more efficient way than it is employed currently, and therefore shows that the used distinction between "cryptic" and "non-cryptic" diversity is an artificial one.

\section{Materials and methods}

Sampling. Material for this study was obtained by scuba diving at widely separated locations in Europe: Denmark, Germany, Ireland, the Netherlands, Norway, Spain, Sweden, Portugal, and the United Kingdom. Specimens were photographed underwater and measured. Magnesium sulphate (7\%) has a relaxing effect on muscles, therefore each specimen was immediately stored in a dilution with seawater $(1: 1)$ at $4{ }^{\circ} \mathrm{C}$ overnight, before preserving in $96 \%$ ethanol. The specimens were deposited in the Zoological Museum of Lomonosov Moscow State University (ZMMU), National Museums Northern Ireland and in Bureau Waardenburg BV, Aquatic ecology, the Netherlands (FD).

Nomenclatural acts. The electronic version of this article in Portable Document Format (PDF) will represent a published work according to the International Commission on Zoological Nomenclature (ICZN), and hence the new name contained in the electronic version is effectively published under that Code from the electronic edition alone. This published work and the nomenclatural acts it contains have been registered in ZooBank, the online registration system for the ICZN. The ZooBank LSIDs (Life Science Identifiers) can be resolved and the associated information viewed through any standard web browser by appending the LSID to the prefix http://zoobank.org/. The LSID for this publication is: [urn:lsid:zoobank.org:pub:15279E86-D7E2-4765-BF22-C0EB01E48E3D]. The online version of this work is archived and available from the following digital repositories: PubMed Central and CLOCKSS.

Morphological analysis. The external and internal morphology was studied using a stereomicroscope and digital cameras (Nikon D-810, Nikon D-7000, Nikon D-600 and Nikon D-80). The buccal masses were extracted and processed in $10 \%$ sodium hypochlorite solution to extract the radula and the jaws. Reproductive systems were examined using the stereomicroscope. The jaws were analyzed under a stereomicroscope and then photographed. The radulae and jaws were rinsed in water and $70 \%$ ethanol, then dried, mounted on stubs using carbon tape, coated with gold and palladium and finally examined using scanning electron microscopes (CamScan Series II and JSM 6380). The images were captured using a maximum quality mode (4) in CamScan II and a 80-s capturing mode in JSM 6380.

Statistical analysis. External morphology features (body length; number of frontal veil appendages, rhinophoral lamellae, and gills) were evaluated statistically using nonparametric Mann-Whitney rank sum test.

Molecular analysis. A total of 102 Polycera specimens of various colour patterns and one Palio dubia were successfully sequenced in the Netherlands and Russia for the mitochondrial cytochrome $c$ oxidase subunit I (COI) gene, and the ribosomal 16S RNA gene (see Supplementary information S1 for 
DNA extraction procedure, and PCR amplification options). All new sequences were deposited in GenBank (Supplementary information, Table S1, highlighted in bold). Original data and publicly available sequences were aligned with the MAFFT algorithm ${ }^{30}$. Separate analyses were conducted for COI ( $\left.658 \mathrm{bp}\right)$, $16 \mathrm{~S}(463 \mathrm{bp})$, and concatenated data $(1121 \mathrm{bp})$. Evolutionary models for each data set were selected using MrModelTest $2.3^{31}$. The GTR $+\mathrm{I}+\mathrm{G}$ model was chosen. Two different phylogenetic methods, Bayesian inference (BI) and Maximum Likelihood (ML), were used to infer evolutionary relationships. Bayesian estimation of posterior probability was performed in MrBayes 3.2 ${ }^{32}$. Four Markov chains were sampled at intervals of 500 generations. Analysis was started with random starting trees and $5 \times 10^{6}$ generations. ML analysis was performed using RAxML 7.2.8 $8^{33}$ with 1000 bootstrap replicates. Final phylogenetic tree images were rendered in FigTree 1.4.2. To evaluate the genetic distribution of the different haplotypes, a haplotype network for the COI molecular data was reconstructed using Population Analysis with Reticulate Trees (PopART, http://popart.otago.ac.nz) with the TCS-network method. The program Mega $7^{34}$ was used to calculate uncorrected p-distances between all sequences. Additionally, Automatic Barcode Gap Discovery $(\mathrm{ABGD})^{35}$ was used to group the sequence data into operational taxonomic units. The alignment from the COI marker for all Polycera specimens under consideration was submitted and processed in ABGD using the Jukes-Cantor (JC69) and Kimura (K80) models with default settings.

Building the periodic-like rows of chromatic variants. Similar chromatic variants within each potential species were aligned using calibration by the degree of light to dark surface pigmentation and transparency of body tissue, including presence of black stripes and brownish/dark pigmentation on the dorsal and lateral sides of the body. These similar forms establish horizontal rows of similar looking specimens within the species (Fig. 1). In total, eight chromatic variants (horizontal rows I-VIII) are recognized: I-body semi-transparent white, orange-yellow spots or brownish/dark colouration completely absent on the dorsal and lateral sides (orange-yellow colouration restricted to the frontal veil appendages, tips of rhinophores, gills, and postbranchial lobes); II-body semi-transparent white, few or indistinct orange-yellow spots present on the dorsal and lateral sides; III-orange-yellow (sometimes with reddish hue) spots are distinct and tend to form lines; IV-in addition to orange-yellow spots blackish or brownish spots or weak lines appeared (in case of lines, mostly in the anterior part of the body); V-in addition to orange-yellow spots, blackish stripes appear (but do not form continuous lines throughout dorsal side), blackish/brownish spots become evident and closer each other; VI-blackish stripes become evident and form continuous lines throughout dorsal side, blackish/brownish spots begin to blend together and form faint stripe-like pattern, orange-yellow spots evident in striped morphs, and less evident or almost absent in spotted morphs; VII-blackish stripes or a brownish (with a greenish hue) colouration pattern become dominant, orange-yellow spots are distinct in striped morphs, and less distinct or almost absent in spotted morphs. VIII-the blackish stripes pattern remains evident or merged, whereas orange-yellow spots (often with more intense reddish colouration) are merged into distinct lines. The proposed scheme of the chromatic variants has a biological basis since it was shown for $P$. quadrilineata s.l. that during the earlier post larval ontogenetic development orange and blackish colouration is weak or almost absent, and distinct spots, lines and stripes appear only towards later ontogenetic stages ${ }^{36}$ and this coincides well with general patterns of the ontogeny among dorid nudibranchs, when colourless or white forms appear first, and intense colouration is added later.

\section{Results}

Morphological and statistical analyses. The scheme of description of the chromatic polymorphism among the monophyletic group of closely related species of Polycera which inhabit European waters is consistently applied to each of the four potential species in this complex (Fig. 1, vertical columns). Among specimens whose external and internal morphology correspond to the descriptions of Polycera quadrilineata and P. capitata, specimens with the colour patterns which correspond to the rows II-VIII were detected (Fig. 1, horizontal rows show eight different color patterns). In P. faeroensis specimens with colour patterns for the rows I-III and VIII were found, whereas for P. kernowensis sp. nov. (holotype ZMMU Op-755, ZooBank registration: urn:lsid:-zoobank.org:act: 5C821EFD-FB12-49D5-A9C3026A325F6D21) specimens with colour patterns corresponding only to row I were found. Afterwards, an additional morphological study in order to detect morphological differences between similar specimens of I-III rows (semitransparent white body and absence/presence yellow-orange spots/lines, that was observed in $42 \%$ among $P$. quadrilineata specimens, used for statistical analysis, $47 \%$ P. capitata, $88 \%$ P. faeroensis, and $100 \%$ of P. kernowensis sp. nov.) (Fig. 1). In the present study it is shown that these similar white-and-yellow specimens of all four species reveal significant statistical differences in number of rhinophoral lamellae $(\mathrm{p}=0.023$ between $P$. quadrilineata and $P$. kernowensis sp. nov.; $\mathrm{p}<0.001$ between all other species). For the number of frontal veil appendages there were no significant statistical differences between $P$. quadrilineata and $P$. capitata. However, such differences were revealed between $P$. faeroensis and $P$. kernowensis sp. nov. $(\mathrm{p}<0.001)$; P. faeroensis compared with P. quadrilineata or P. capitata $(\mathrm{p}<0.001)$; P. kernowensis sp. nov. compared with P. quadrilineata or $P$. capitata $(\mathrm{p}<0.001)$. There were no significant statistical differences in number of gills for $P$. quadrilineata, P. capitata, and $P$. faeroensis. But $P$. kernowensis sp. nov. shows statistically significant fewer gills compared with $P$. quadrilineata, $P$. capitata, and $P$. faeroensis $(\mathrm{p}<0.001)$ (Fig. 2 A, Table 1, Table S2). It is unmistakably visible that $P$. faeroensis commonly possesses more than one pair of postbranchial lobes (Fig. 2B). Significant statistical differences in external morphology were revealed for specimens of all colour patterns (Supplementary information, Fig. S1). Mean $P$. faeroensis body length is statistically significantly bigger than mean body length of $P$. 


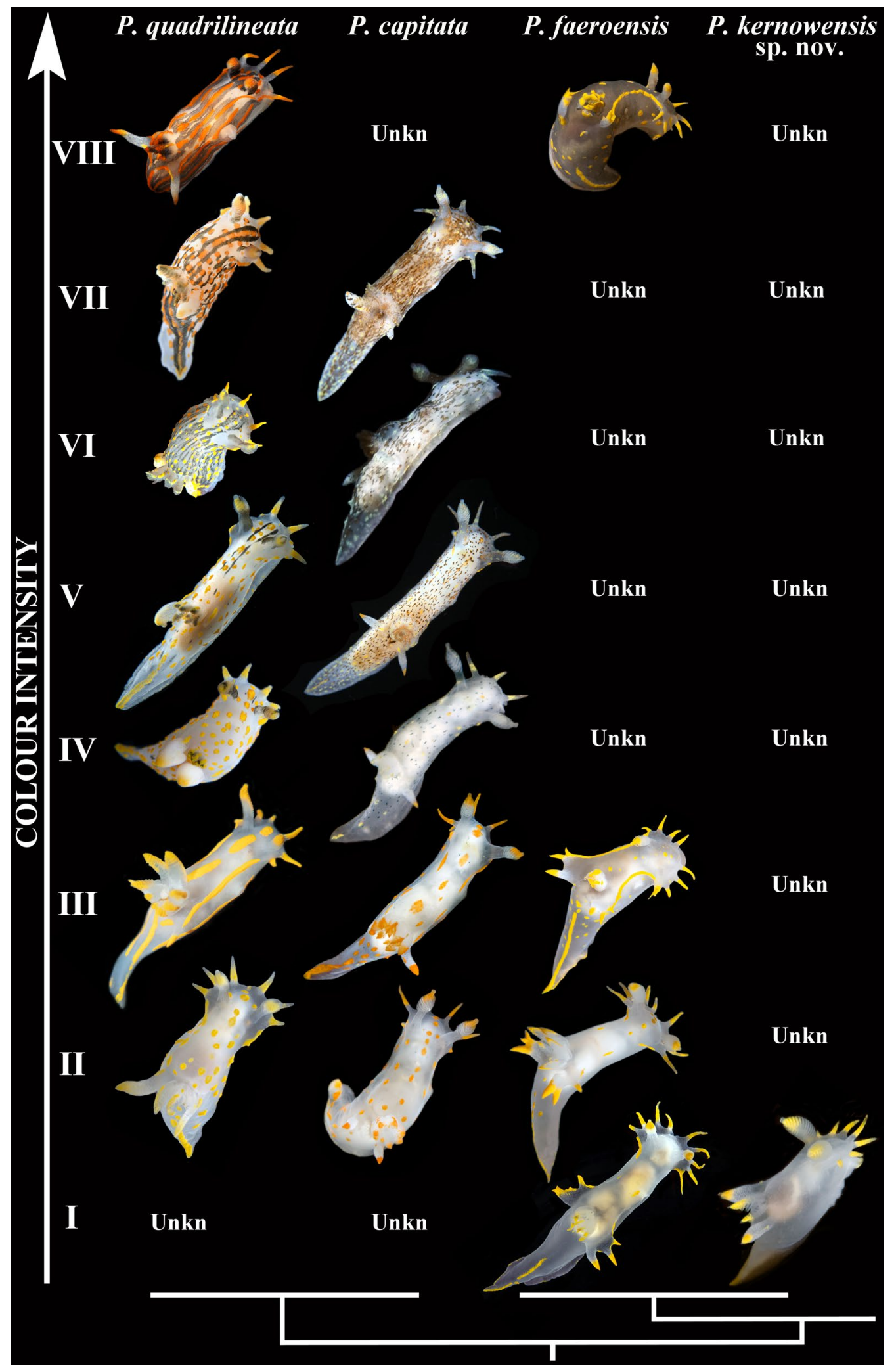

Figure 1. Periodic-like presentation of chromatic variation patterns among species within European Polycera, represented as vertical rows. Eight main periods (horizontal rows, roman numerals) are presented whereas spotless body/colourless forms are at the bottom and forms with a maximal number of spots/coloured are at the top. Non-observed forms for each particular species are indicated as "unkn" = "unknown". 
A

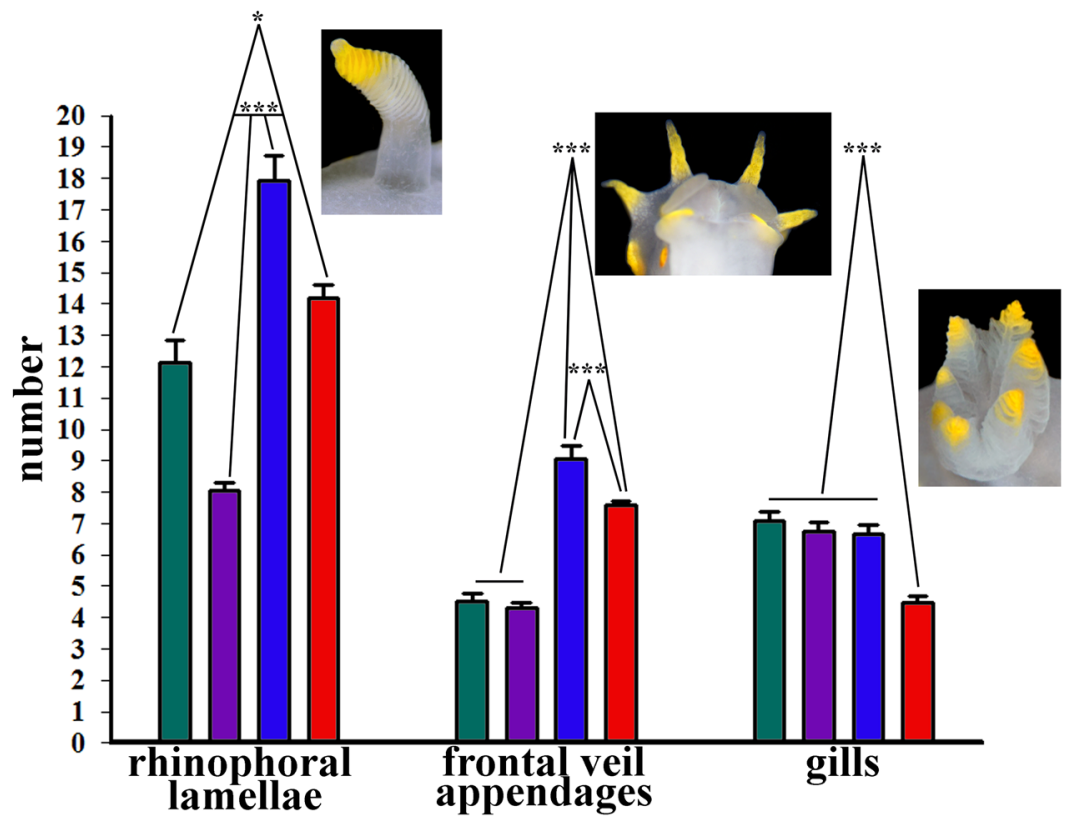

B
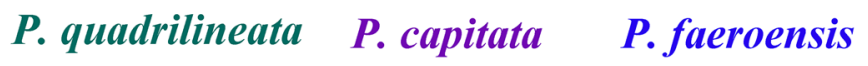

P. kernowensis
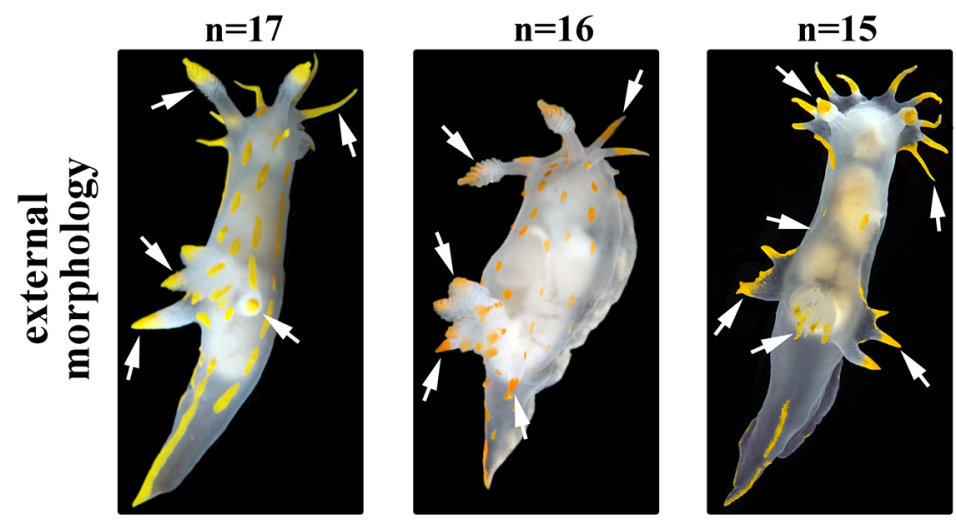

sp. nov.
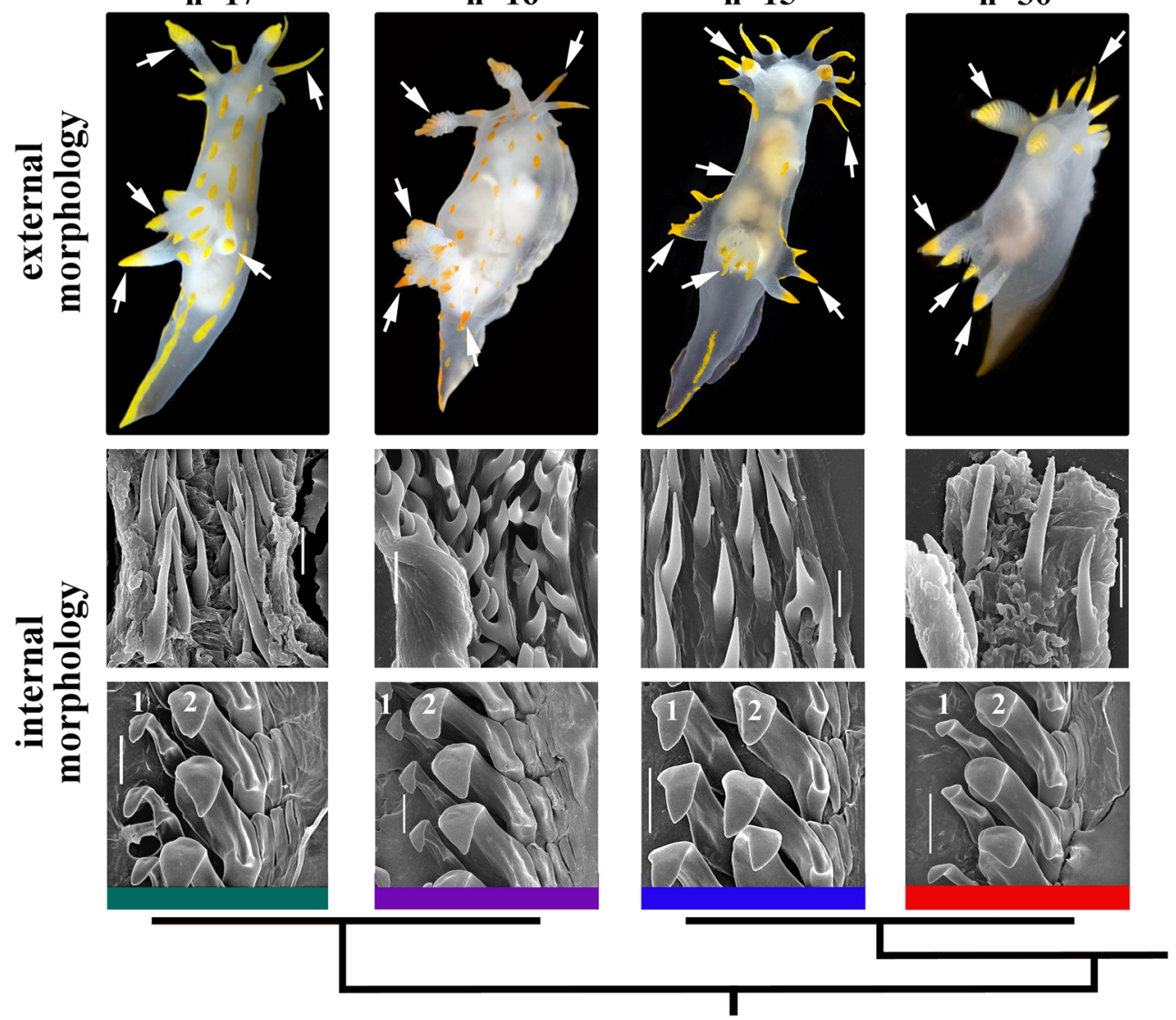

Figure 2. Statistical analysis (A) of the external diagnostic characters (indicated by arrows) among white and orange colour variants of detected species within European Polycera (mean \pm the standard error of the mean), and presentation of the internal diagnostic features (B). Scale bars: all radulae $-100 \mu \mathrm{m}$, all spines $-10 \mu \mathrm{m}$. 


\begin{tabular}{|c|c|c|c|c|}
\hline & P. quadrilineata & P. capitata & P. faeroensis & P. kernowensis sp. nov \\
\hline Length $(\mathrm{mm})$ & Max. 45 & Max. 16 & Max. 45 & Max. 20 \\
\hline Reported chromatic variants & II-VIII & II-VII & I-III, VIII & I \\
\hline Chromatic differences & $\begin{array}{l}\text { Few or numerous blackish stripes } \\
\text { in chromatic variants IV-VII }\end{array}$ & $\begin{array}{l}\text { Few or numerous blackish or } \\
\text { brownish (with greenish hue) } \\
\text { spots present in chromatic variants } \\
\text { IV-VII }\end{array}$ & $\begin{array}{l}\text { Chromatic variants IV-VII not } \\
\text { known }\end{array}$ & $\begin{array}{l}\text { Chromatic variants II-VIII had } \\
\text { not known }\end{array}$ \\
\hline Number of frontal veil appendages & Mean 4-5, max. 7 & Mean 4-5, max. 6 & Mean 8-9, max. 14 & Mean 7-8, max. 9 \\
\hline $\begin{array}{l}\text { Number of lamellae of rhino- } \\
\text { phores }\end{array}$ & Mean 11-12, max. 17 & Mean 8, max. 11 & Mean $18-19$, max. 25 & Mean 14-15, max. 22 \\
\hline Number of gills & Mean 6-7, max. 11 & Mean 6-7, max. 9 & Mean 6-7, max. 11 gills & Mean 4-5, max. 7 gills \\
\hline Postbranchial lobes & Simple (rarely bifurcated), one pair & Simple, one pair & $\begin{array}{l}\text { Compound ( } 2-5 \text { pairs plus smaller } \\
\text { tubercles; if simple-looking lobes, } \\
\text { several smaller tubercles present } \\
\text { in addition) }\end{array}$ & Simple, one pair \\
\hline Jaws & $\begin{array}{l}\text { With moderately narrow shoulders } \\
\text { and strong, distinct wing-like } \\
\text { expansions }\end{array}$ & $\begin{array}{l}\text { With moderately narrow shoulders } \\
\text { and distinct wing-like expansions, } \\
\text { delicate }\end{array}$ & $\begin{array}{l}\text { With broad, rounded shoulders, } \\
\text { without distinct wing-like expan- } \\
\text { sions }\end{array}$ & $\begin{array}{l}\text { With moderately narrow } \\
\text { shoulders, and distinct wing-like } \\
\text { expansions }\end{array}$ \\
\hline Reported radula formula & $\begin{array}{l}9-20 \times \\
0-5 \cdot 1 \cdot 1 \cdot 0 \cdot 1 \cdot 1 \cdot 0-5\end{array}$ & $\begin{array}{l}9-10 \times \\
0-5 \cdot 1 \cdot 1 \cdot 0.1 \cdot 1.0-5(6 ?)\end{array}$ & $\begin{array}{l}11-16 \times \\
0-3 \cdot 1 \cdot 1 \cdot 0 \cdot 1 \cdot 1 \cdot 0-3\end{array}$ & $\begin{array}{l}7-11 \times \\
0-4 \cdot 1 \cdot 1 \cdot 0.1 \cdot 1.0-4\end{array}$ \\
\hline First and second inner lateral teeth & $\begin{array}{l}\text { First teeth differ in shape from } \\
\text { second one, usually larger }\end{array}$ & $\begin{array}{l}\text { First teeth differ in shape from } \\
\text { second one, usually larger }\end{array}$ & $\begin{array}{l}\text { First teeth similar in shape and } \\
\text { size to second one }\end{array}$ & $\begin{array}{l}\text { First teeth differ in shape from } \\
\text { second one, usually larger }\end{array}$ \\
\hline Outer lateral teeth number & Up to 5 (5 is more common) & Up to $5(6 ?)$ (4 is more common) & Up to 3 & Up to 4 \\
\hline Middle cusp of first lateral teeth & $\begin{array}{l}\text { Distinct in majority of radular } \\
\text { teeth }\end{array}$ & $\begin{array}{l}\text { Distinct in majority of radular } \\
\text { teeth }\end{array}$ & Not evident & $\begin{array}{l}\text { Evident in the posterior rows of } \\
\text { radula }\end{array}$ \\
\hline Ampulla & $\begin{array}{l}\text { Relatively large, conspicuously } \\
\text { bent in middle part }\end{array}$ & $\begin{array}{l}\text { Relatively small, somewhat } \\
\text { enlarged in the proximal part }\end{array}$ & $\begin{array}{l}\text { Relatively large, conspicuously } \\
\text { bent in middle part }\end{array}$ & $\begin{array}{l}\text { Relatively small, not evidently bent } \\
\text { in middle part }\end{array}$ \\
\hline Bursa copulatrix & Large, elongate & Medium-sized, widened, oval & Very large, elongate & Large, elongate \\
\hline Vas deferens & $\begin{array}{l}\text { Relatively long, distinctly widened } \\
\text { distally }\end{array}$ & $\begin{array}{l}\text { Relatively long, not widened } \\
\text { distally }\end{array}$ & Very long, not widened distally & $\begin{array}{l}\text { Relatively long, not widened } \\
\text { distally }\end{array}$ \\
\hline Copulative spines & $\begin{array}{l}\text { Needle-shaped, straight or winding } \\
\text { or shorter cones }\end{array}$ & $\begin{array}{l}\text { Short hooks or short to elongate } \\
\text { cones }\end{array}$ & $\begin{array}{l}\text { Long, straight or slightly bent } \\
\text { spines or shorter more elongate } \\
\text { cones with a peculiar base with } \\
\text { a hole }\end{array}$ & Elongate, somewhat hooked cones \\
\hline
\end{tabular}

Table 1. Verified and updated comparison of key diagnostic characters of the European Polycera species complex based on the multilevel organismal diversity approach. The characters are given for adults or subadults individuals.

quadrilineata, P. capitata, and P. kernowensis sp. nov. Mean P. capitata and P. kernowensis sp. nov. body length is statistically significantly smaller than mean body length of $P$. quadrilineata and $P$. faeroensis $(\mathrm{p}<0.001$, Fig. S1, Table S2). In addition, differences in internal morphology were revealed (Fig. 2B). $P$. capitata have clear differences from the other species in shape of the copulative spines. P. faeroensis have clear differences in shape and size of the lateral teeth of radula.

Molecular phylogenetic analysis. Phylogenetic analysis was performed using 197 specimens of Polycera, including data for 178 P. quadrilineata species complex (102 of which were preliminarily divided into four groups using the methods described above and data for 76 downloaded from GenBank), and 24 outgroup specimens. The dataset consisted of 356 nucleotide sequences including COI and 16S genes. Bayesian Inference (BI) and Maximum Likelihood (ML) analyses based on the combined dataset for the COI, and $16 \mathrm{~S}$ genes yielded similar results (Fig. 3). To define species, we use a set of methods ${ }^{12,37}$ including phylogenetic tree topologies, ABGD analysis, pairwise distances and the haplotype network containing phylogeographic data rendered using PopART (Fig. 4, Table 2). The results of this study confidently confirmed the presence of four species among $P$. quadrilineata similar specimens that coincided with species detected before the molecular study: P. quadrilineata, P. capitata (that do not show any differences from the recently described $P$. norvegica), $P$. faeroensis, and $P$. kernowensis sp. nov. A clade containing $P$. quadrilineata $(\mathrm{n}=92, \mathrm{PP}=1, \mathrm{BS}=99)$ has the closest position to the clades containing $P$. capitata $(\mathrm{n}=34)$ combined with former $P$. norvegica $(\mathrm{n}=17, \mathrm{PP}=1, \mathrm{BS}=100)$, P. faeroensis $(\mathrm{n}=2, \mathrm{PP}=1, \mathrm{BS}=100)$, P. kernowensis sp. nov. $(\mathrm{n}=33, \mathrm{PP}=1, \mathrm{BS}=100)$, and two Polycera sp. A from South Africa $(\mathrm{PP}=1, \mathrm{BS}=100)$. $P$. quadrilineata and $P$. capitata (combined with former $P$. norvegica) clustered in two distinct and well separated sister clades that formed the sister group to $P$. faeroensis, $P$. kernowensis sp. nov., and $P$. sp. A, which are clustered together in a separate clade, wherein $P$. faeroensis has sister position to $P$. kernowensis sp. nov. The ABGD analysis of the COI data set run with two different models are fully concordant with the clades in the molecular phylogenetic analysis (Fig. 3). Results obtained by PopART showed a network of haplotypes that clearly clustered into four distinct groups coincident with $P$. quadrilineata, $P$. capitata (combined with former $P$. norvegica), $P$. faeroensis, and $P$. kernowensis sp. nov. (Fig. 4). While no correlation was found between the molecular characteristic for each of the four species and the geographical 


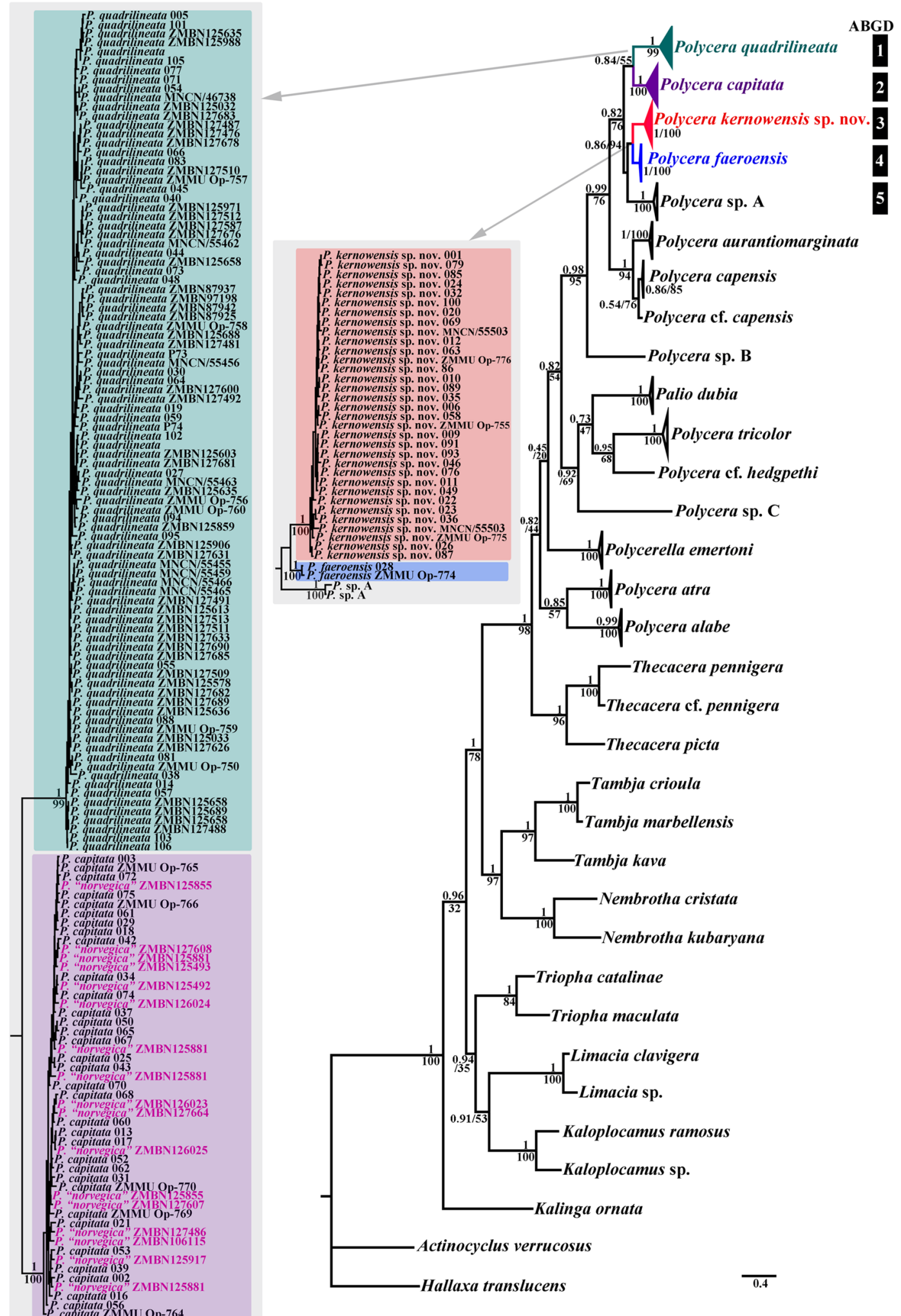

Figure 3. Phylogenetic relationships of Polycera specimen based on COI $+16 \mathrm{~S}$ concatenated dataset inferred with Bayesian (BI) inference. Numbers above branches represent the posterior probabilities from BI. Numbers below branches indicate the bootstrap values for Maximum Likelihood (ML). 


\section{- Polycera quadrilineata \\ - Polycera capitata \\ - Polycera "norvegica" \\ - Polycera faeroensis \\ - Polycera kernowensis sp. nov.}

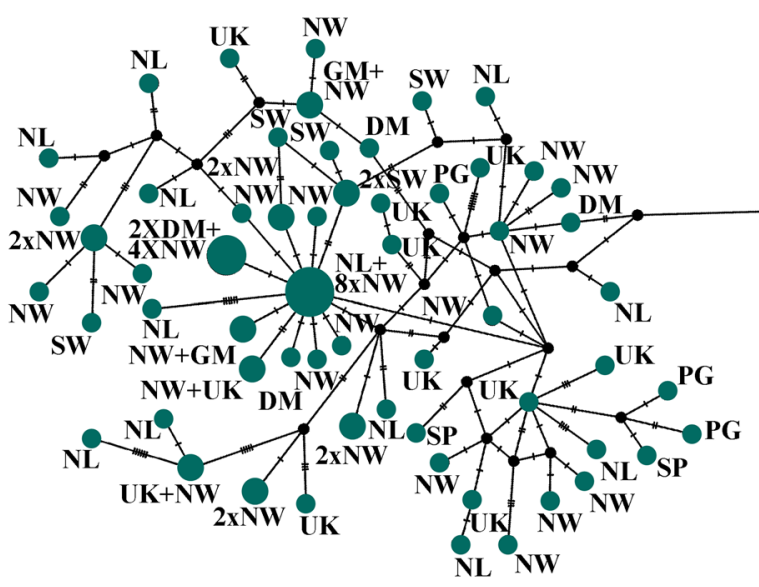

10 samples

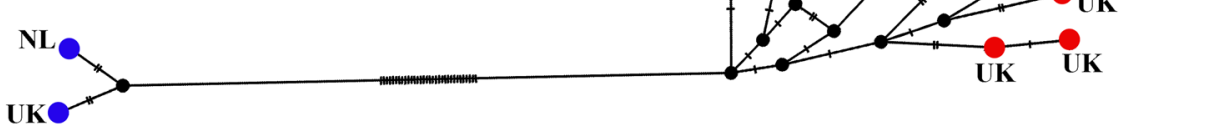

Figure 4. The haplotype network for Polycera specimens based on cytochrome c oxidase subunit I (COI) molecular data (642 bp). Phylogeographic data are represented within a broad geographic framework. Each circle represents one haplotype, the circle area indicates the occurrence rate. Each cluster (species) is coloured individually ( $P$. quadrilineata in green, $P$. capitata in purple, " $P$. norvegica" in pink, $P$. faeroensis in blue and $P$. kernowensis sp. nov. in red.). DM Denmark, GM Germany, IR Ireland, $N L$ Netherlands, $N W$ Norway, $P G$ Portugal, SP Spain, SW Sweden, UK United Kingdom.

distribution of each of the four species from this complex, P. capitata and " $P$. norvegica" recently described from Norway have a widespread distribution in England, Ireland and Norway, and do not show separate clustering. Regarding the supposedly fast-evolving COI marker, uncorrected p-distances within the $P$. quadrilineata clade range $0-3.36 \%$. Whereas minimal uncorrected p-distances between the P. quadrilineata clade and $P$. capitata (combined with $P$. norvegica), $P$. faeroensis, and $P$. kernowensis sp. nov. clades are $9.44 \%, 11.09 \%$, and $10.79 \%$ respectively. Uncorrected COI p-distances within the P. capitata (combined with $P$. norvegica) clade range from 0.15 to $3.04 \%$. Minimal uncorrected p-distances between the $P$. capitata (combined with P. norvegica) clade and P. faeroensis, and P. kernowensis sp. nov. clades are $8.52 \%$, and $8.66 \%$ respectively. Uncorrected COI p-distances within the $P$. faeroensis clade are $0.61 \%$; within the $P$. kernowensis sp. nov. clade range $0-2.33 \%$. Uncorrected COI p-distances between $P$. faeroensis and $P$. kernowensis sp. nov. clades range from 5.47 to $6.38 \%$ (Table 2).

Polycera aurantiomarginata García-Gómez \& Bobo, 1984, which was described from Spain and which is also distributed on the West African coasts ${ }^{22}$ belongs to a different Polycera clade, considerably different morphologically, and hence is not part of the complex of the European species closely related to $P$. $q u a d r i l i n e a t a$. Therefore P. aurantiomarginata is included in the present molecular phylogenetic analysis, 


\begin{tabular}{|l|l|l|l|l|l|}
\hline & P. quadrilineata & $\begin{array}{l}\text { P. capitata (including } \boldsymbol{P .} \\
\text { norvegica syn.nov.) }\end{array}$ & P. faeroensis & P. kernowensis sp. nov & P. sp. A \\
\hline P. quadrilineata & $\mathbf{0 - 3 . 3 6}$ & $9.44-12.68$ & $11.09-13.13$ & $10.79-14.53$ & $10.42-12.5$ \\
\hline $\begin{array}{l}\text { P. } \text { capitata (including P. nor- } \\
\text { vegica syn.nov.) }\end{array}$ & $9.44-12.68$ & $\mathbf{0 . 1 5 - 3 . 0 4}$ & $8,52-9.97$ & $8.66-11.99$ & $9.95-11.21$ \\
\hline P. faeroensis & $11.09-13.13$ & $8.52-9.97$ & $\mathbf{0 . 6 1}$ & $5.47-6.38$ & 8.09 \\
\hline P. kernowensis sp. nov & $10.79-14.53$ & $8.66-11.99$ & $5.47-6.38$ & $\mathbf{0 - 2 . 3 3}$ & $8.71-10.42$ \\
\hline P. sp. A & $10.42-12.5$ & $9.95-11.21$ & 8.09 & $8.71-10.42$ & $\mathbf{1 . 4}$ \\
\hline
\end{tabular}

Table 2. Intragroup (highlighted in bold) and Intergroup genetic distances (\%) for COI in the European Polycera species complex.

but not considered in this study in detail (Fig. 3). An undescribed species ("Polycera sp. A") which was included to a molecular phylogenetic study without any morphological data ${ }^{14}$ is basal to the clade of the European Polycera (Fig. 3) but occurs exclusively in South Africa and is out of scope in the present study. For Polycera marplatensis Franceschi, $1928^{38}$ which is partly similar to P. quadrilineata molecular data are not available, but this species occurs exclusively in South America and therefore is also out of scope of the present study.

The morphological analysis data were confirmed by molecular phylogenetic results. P. quadrilineata, $P$. capitata, P. faeroensis, and P. kernowensis sp. nov. are four separate species in the genus Polycera. P. capitata and former $P$. norvegica are the same species.

Difficult to distinguish European species within the genus Polycera: recognition of the involved species. We obtained a very robust framework of four closely related species from European waters: Polycera quadrilineata, P. capitata, P. faeroensis and P. kernowensis sp. nov. (Figs. 3, 4, for detailed systematic account of all four species see Supplementary information S2). Polycera quadrilineata and $P$. capitata are the two common European species and usually present in the shallow marine waters at depths easily accessible for diving (ca. 5-40 m), making these species always a focus of attention of various environmental associations, ecological studies and currently also citizen scientists. Therefore it is of high general importance to present a framework for morphological identification of these species complex based on robust molecular data (Tables 1,2 ).

Throughout the history of nudibranch studies in Europe, a species similar, but distinct from $P$. faeroensis has been confused with the latter and was never taxonomically recognized ${ }^{14,39,40}$. In the present study this species using robust molecular framework based on a broad geographical sampling and significant external and internal morphological differences (Figs. 1, 2, 9; Table 1) it is for the first time recognized and described as a new species, Polycera kernowensis sp. nov. (see details in Supplementary information S2). This species has significantly more rhinophoral lamellae (14-15) than in P. capitata (8) and P. quadrilineata (11-12) and same is true for the frontal veil appendages (7-8 vs. 4-5) including specimens of similar sizes (Figs. 2, Supplementary information Fig. S1). Polycera quadrilineata can reach a similar large size as $P$. faeroensis (commonly the former species is smaller), but the mean number of rhinophoral lamellae in P. quadrilineata is significantly smaller (11-12), than in $P$. faeroensis (18-19) (Figs. 2, Fig. S1) and even in largest specimens of $P$. quadrilineata the number of rhinophoral lamellae is smaller than in $P$. faeroensis. In addition, the number of the frontal veil appendages differs with a high support among these three species (Fig. 2, Supplementary information S2, Fig. S1).

Remarkably, in this study we also recovered two closely related species $P$. quadrilineata and $P$. capitata as sister species (Fig. 3), in contrast to a previous study ${ }^{14}$, because taxon selection was previously not exhaustive. True $P$. faeroensis is a more rarely encountered species than $P$. quadrilineata and $P$. capitata (at least in the relatively shallow water environments) and verified molecular data which were aligned with the fine-scale morphological data are presented in this study for the first time (Figs. 1, 2, 3, 4, 5, 6, 7, 8, 9, 10). Previously real P. faeroensis were misidentified ${ }^{14,40}$ with its new sister species, here described as $P$. kernowensis sp. nov. (Figs. 8, 9). Our verified data on the morphology of the radula matched well with the original description of $P$. faeroensis from the Faeroe Islands ${ }^{41}$ and a morphological redescription from Sweden ${ }^{42}$. 

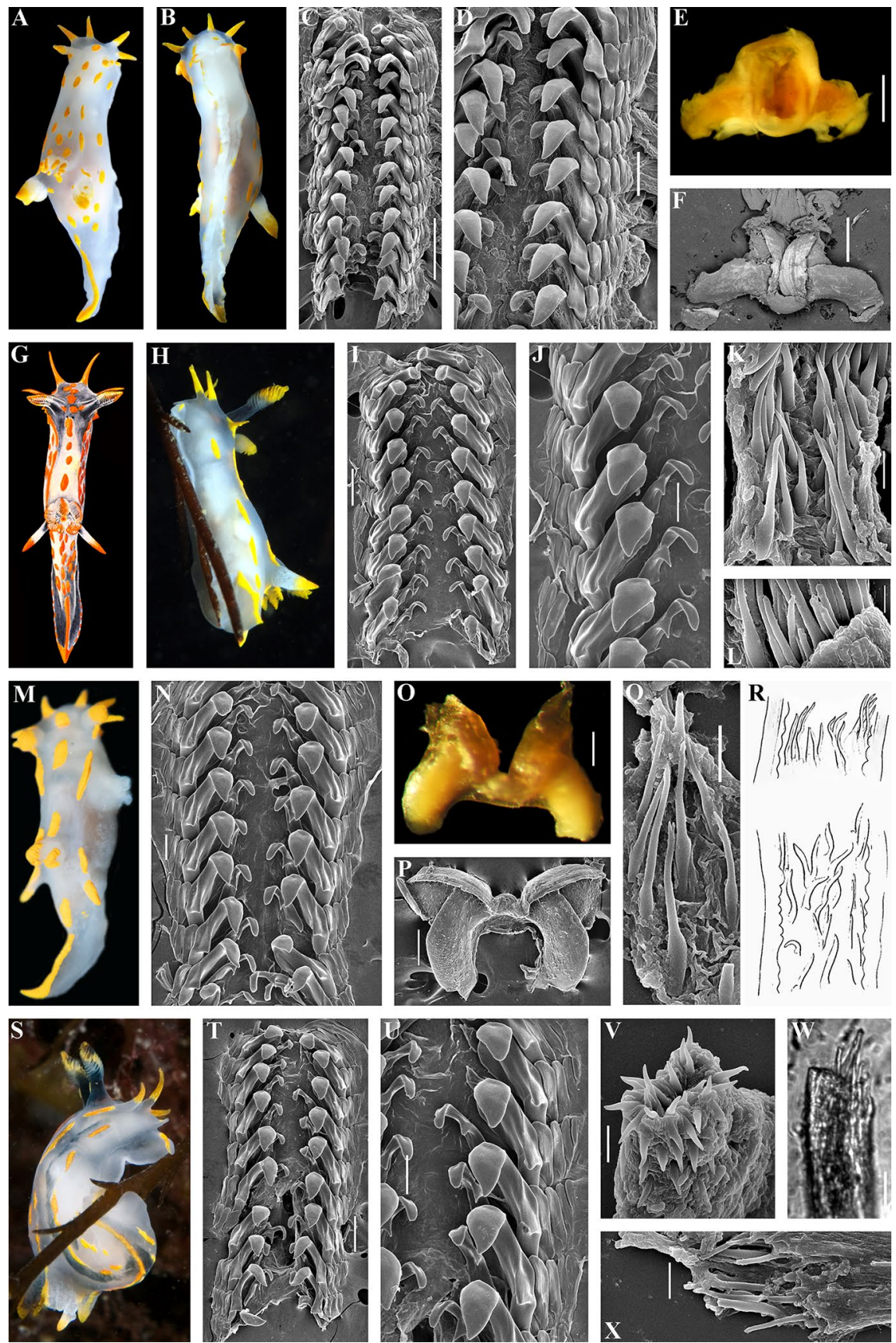

Figure 5. Polycera quadrilineata (O.F. Müller, 1776). External and internal morphology, light and scanning electron microscopy and comparison with data from Thompson and Brown ${ }^{40}$ and $\mathrm{Bergh}^{46}$. (A) Neotype from Norway, Gulen, dorsal view, $25 \mathrm{~mm}$ in length, live (ZMMU Op-750). (B) Same, ventral view. (C) Radula, neotype, scanning electron microscopy (SEM). (D) Same, radula details. (E) Jaws, neotype, light microscopy. (F) Same, SEM. (G) Specimen from United Kingdom, Skomer Island, depicted in Thompson and Brown $\left({ }^{40}\right.$ : pl 18, a). H. Specimen from United Kingdom, Cornwall, Porthkerris, dorsolateral view, live (ZMMU Op-758). (I) Radula, SEM (ZMMU Op-758). (J) Same, radula details. (K) Copulative spines, SEM (ZMMU Op-758). (L) Same, details. (M) Specimen from Portugal, Setubal, dorsal view, live (ZMMU Op-760). (N) Radula, SEM (ZMMU Op-760). (O) Jaws, light microscopy (ZMMU Op-760). (P) Same, SEM. (Q) Copulative spines, SEM (ZMMU Op-760). (R) Spines of a specimen from Norway depicted in Bergh $\left({ }^{46}\right.$, not in copyright), essentially similar to our present data. (S) Specimen from United Kingdom, Cornwall, Porthkerris, dorsolateral view, live (ZMMU Op-756). (T) Radula, SEM (ZMMU Op-756). (U) Same, radula details. (V) Copulative spines from the tip of everted part (shorter than common ones), SEM (ZMMU Op-756). (W) Copulative spines (common type), light microscopy (FD 041). (X) Same, SEM. Scale bars: c, e, f-500 $\mu \mathrm{m}, \mathrm{d}, \mathrm{i}, \mathrm{j}, \mathrm{o}, \mathrm{p}, \mathrm{t}-200 \mu \mathrm{m}, \mathrm{k}, \mathrm{q}, \mathrm{v}, \mathrm{w}$, $\mathrm{x}-10 \mu \mathrm{m}, \mathrm{l}-5 \mu \mathrm{m}, \mathrm{n}, \mathrm{u}-100 \mu \mathrm{m}$. Photographs: Tatiana Korshunova: (a, b); F.M.F. Driessen (h), (s); Bernard Picton (m). Reproduction of figure from Thompson and Brown ${ }^{40}$ with permission of Gregory Brown, original artist and copyright holder of the images. SEM micrographs and light microscopy photographs: Alexander Martynov. 
A
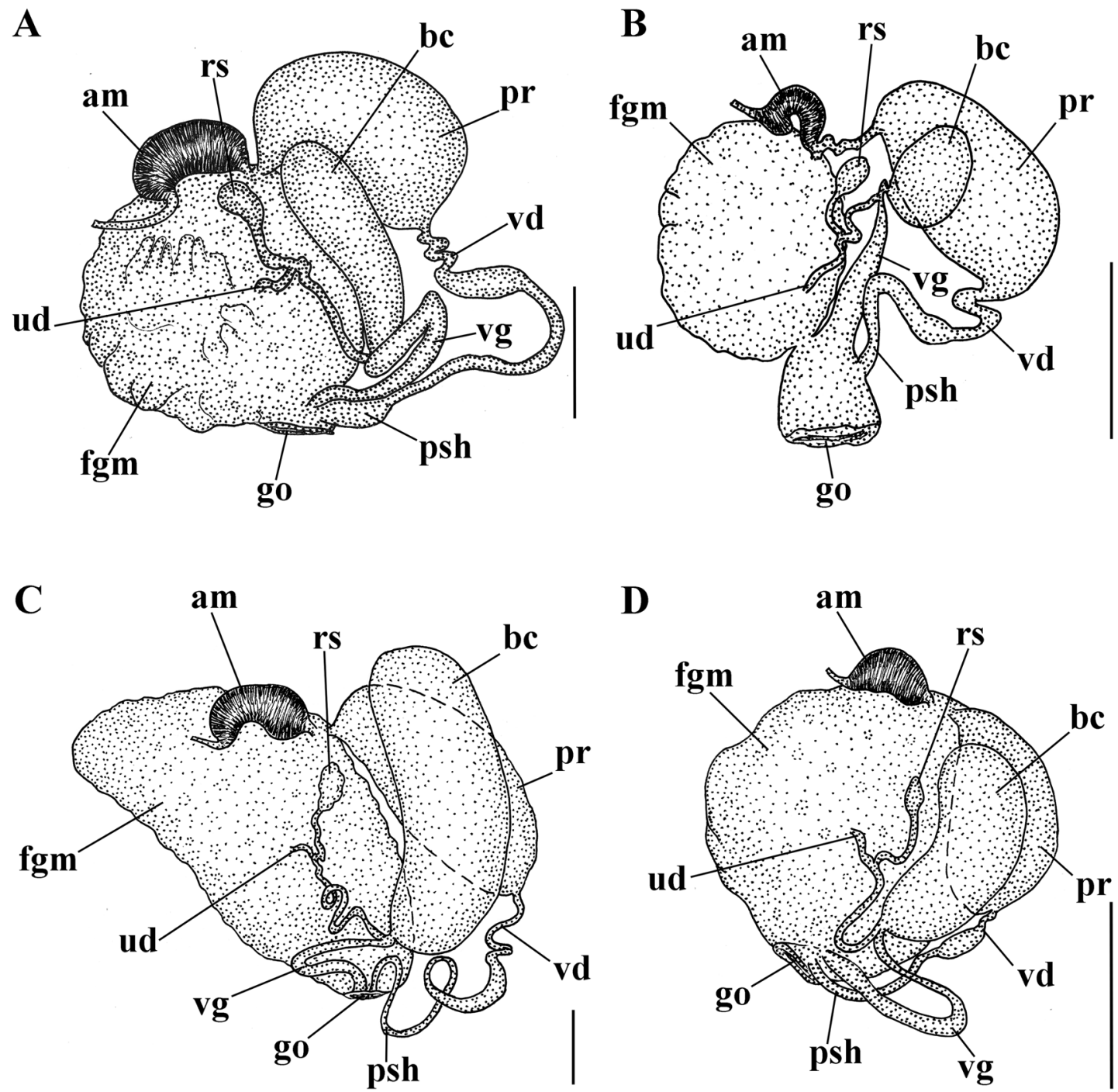

Figure 6. Schemes of the reproductive systems. (A) Polycera quadrilineata. (B) P. capitata. (C) P. faeroensis. (D) $P$. kernowensis sp. nov. am ampulla, $b c$ bursa copulatrix, $f g m$ female gland mass, $g o$ genital opening, $p r$ prostate, $p s h$ penial sheath, $r s$ receptaculum seminis, $u d$ uterine duct, $v d$ vas deferens, $v g$ vagina. Scale bars: $1 \mathrm{~mm}$. 

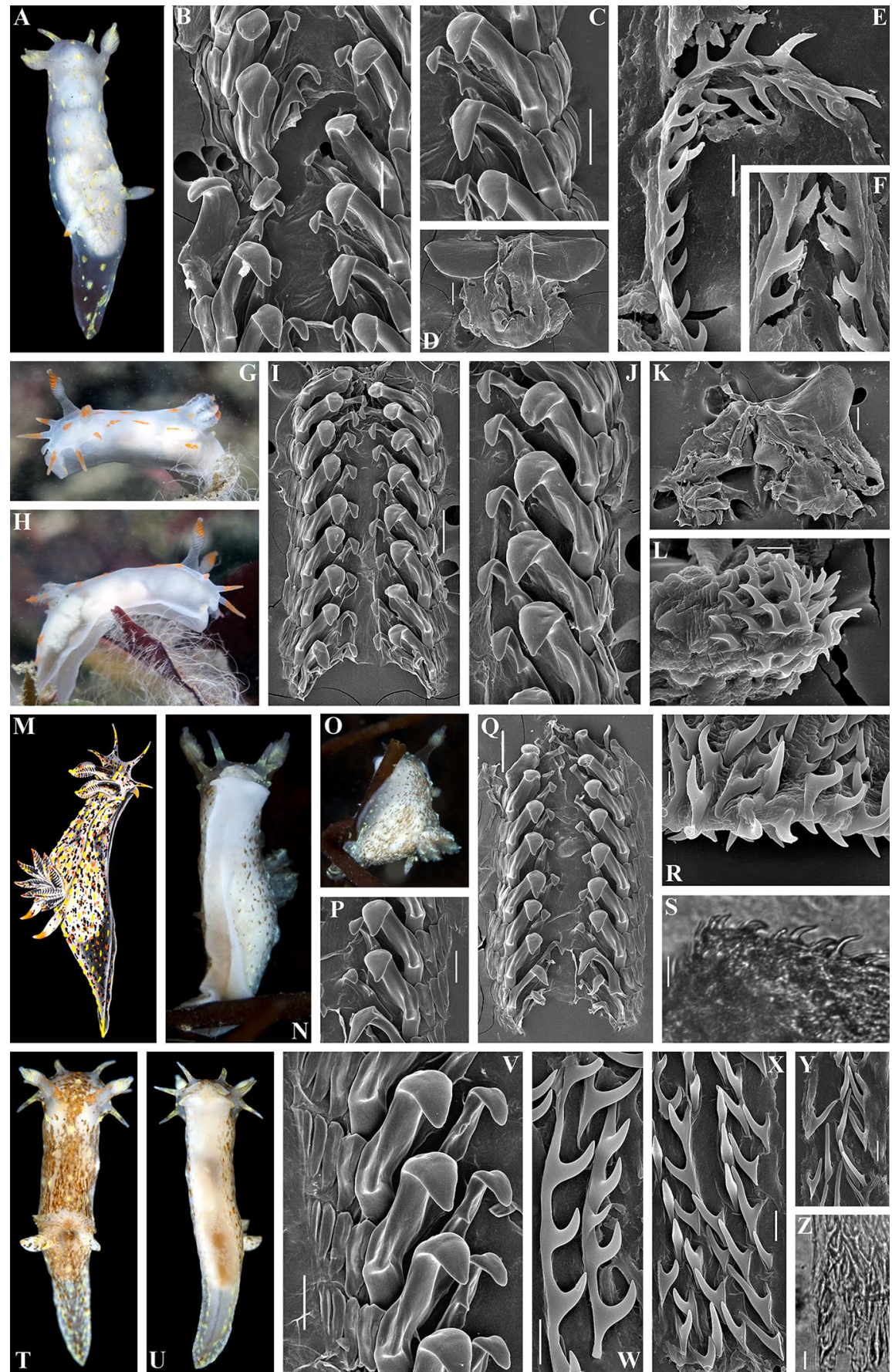

Figure 7. Polycera capitata (Alder \& Hancock, 1854) ${ }^{49}$. External and internal morphology, light and scanning electron microscopy and comparison with data from Thompson and Brown ${ }^{40}$. (A) Specimen from United Kingdom, Cornwall, Porthkerris, dorsal view, live (ZMMU Op-766). (B) Radula, SEM (ZMMU Op-766). (C) Same, radula details. (D) Jaws, SEM. (E) Copulative spines, SEM (ZMMU Op-766). (F) Same, details. (G) Specimen from United Kingdom, Cornwall, Porthkerris, dorsal view, live (ZMMU Op-764). (H) Same, lateroventral view. (I) Radula, SEM (ZMMU Op-764). (J) Same, details. (K) Jaws, SEM (ZMMU Op-764). (L) Copulative spines, SEM (ZMMU Op-764). (M) Specimen from United Kingdom, Lundy Island, depicted in Thompson and Brown $\left({ }^{40}: \mathrm{pl} 18, \mathrm{c}\right)$. (N) Specimen from United Kingdom, Cornwall, Porthkerris, ventral view, live (ZMMU Op-765). (O) Same, ventral view. (P) Radula, details, SEM (ZMMU Op-765). (Q) Radula (ZMMU Op-765). (R) Copulative spines, SEM (ZMMU Op-765). (S) Same, light microscopy. (T) Specimen from Ireland, Mullaghmore, Sligo, dorsal view (ZMMU Op-770). (U) Same, ventral view. (V) Radula, details, SEM (ZMMU Op-770). (W-Y) Copulative spines, details, SEM (ZMMU Op-770). (Z) Same, light microscopy. Scale bars: b-d, j, k, p, v-100 $\mu \mathrm{m}, \mathrm{i}, \mathrm{q}-200 \mu \mathrm{m}, \mathrm{e}, \mathrm{f}, \mathrm{l}, \mathrm{s}, \mathrm{w}-\mathrm{z}-10 \mu \mathrm{m}, \mathrm{r}-5 \mu \mathrm{m}$. Photographs: F.M.F. Driessen (a), (g), (h), (n), $(\mathrm{o})$; Bernard Picton $(\mathrm{t}),(\mathrm{u})$. Reproduction of figure from Thompson and Brown ${ }^{40}$ with permission of Gregory Brown, original artist and copyright holder of the images. SEM micrographs and light microscopy photographs: Alexander Martynov, Tatiana Korshunova. 

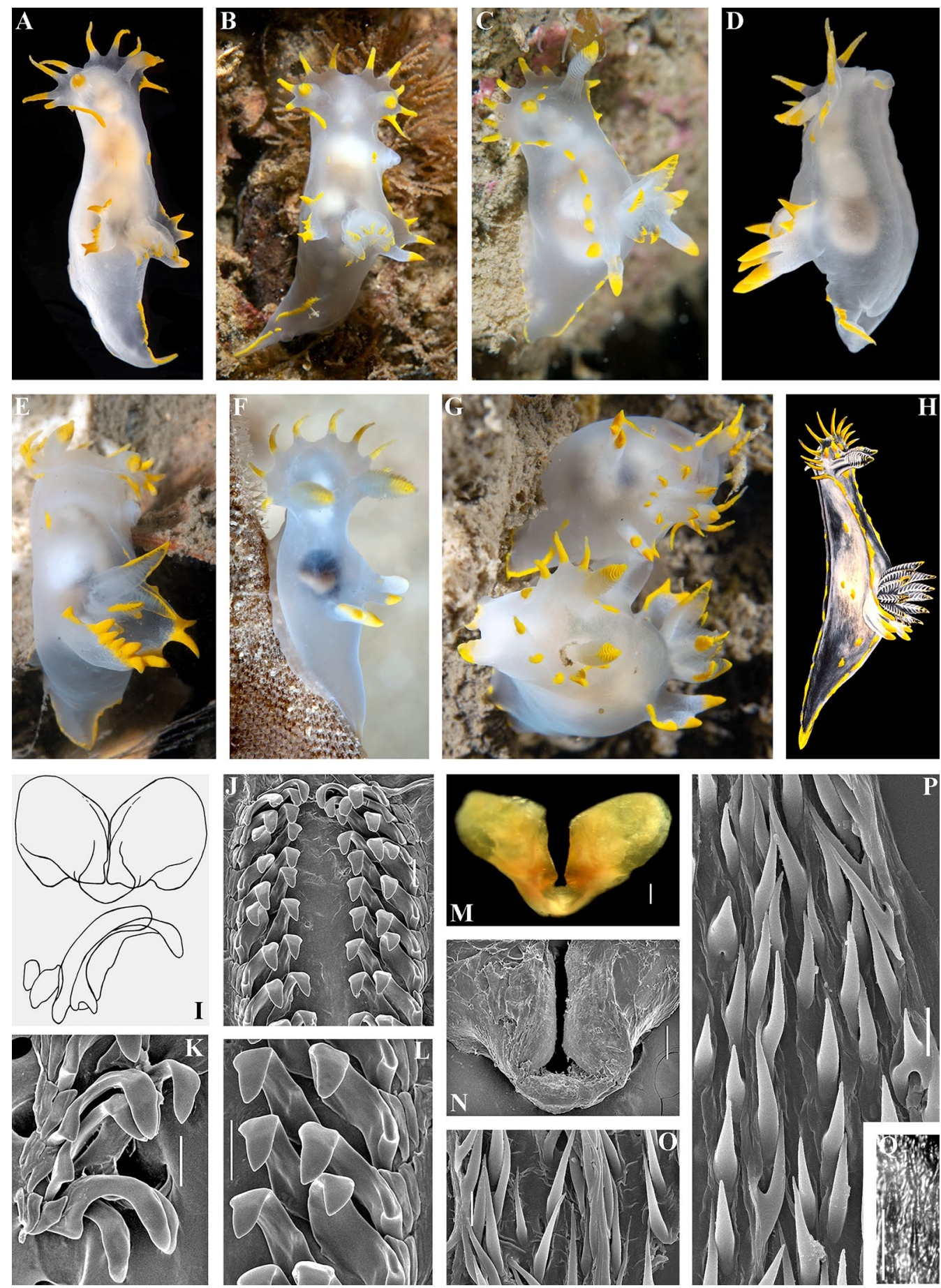

Figure 8. Polycera faeroensis Lemche, $1929^{41}$. External and internal morphology, light and scanning electron microscopy and comparison with data from Thompson and Brown ${ }^{40}$. (A, B) Specimen from United Kingdom, Belfast Lough, Northern Ireland, dorsal views, live (ZMMU Op-774). (C) Specimen from United Kingdom, Strangford Lough, Northern Ireland, dorsolateral view, live. (D) Another specimen from Strangford Lough, Northern Ireland, lateral view, live. (E) Specimen from the United Kingdom, Skomer Island, Pembrokeshire, dorsal view, live. (F) Juvenile specimen from the Strangford Lough, dorsal view, live. (G) Copulating specimens from Skomer Island, Pembrokeshire, Wales, dorsal views. (H) Specimen from United Kingdom, Isle of Man, depicted in Thompson and Brown $\left({ }^{40}: \mathrm{pl} \mathrm{18,g).} \mathrm{(I)} \mathrm{Schemes} \mathrm{of} \mathrm{jaws} \mathrm{(above)} \mathrm{and} \mathrm{radula} \mathrm{teeth} \mathrm{(below)} \mathrm{of}\right.$ holotype from the Faeroe Islands. (J) Radula, SEM (ZMMU Op-774). (K, L) Same, details of radula. (M) Jaws, light microscopy (ZMMU Op-774). (N) Same, details, SEM. (O, P) Copulative spines, SEM (specimen from Belfast Lough). (Q) Same, light microscopy. Scale bars: j-l-100 $\mu \mathrm{m}, \mathrm{m}, \mathrm{n}-200 \mu \mathrm{m}, \mathrm{o}-\mathrm{q}-10 \mu \mathrm{m}$. Photographs: Bernard Picton (a-g). Reproduction of figure from Thompson and Brown ${ }^{40}$ with permission of Gregory Brown, original artist and copyright holder of the images. SEM micrographs and light microscopy photographs: Alexander Martynov. 

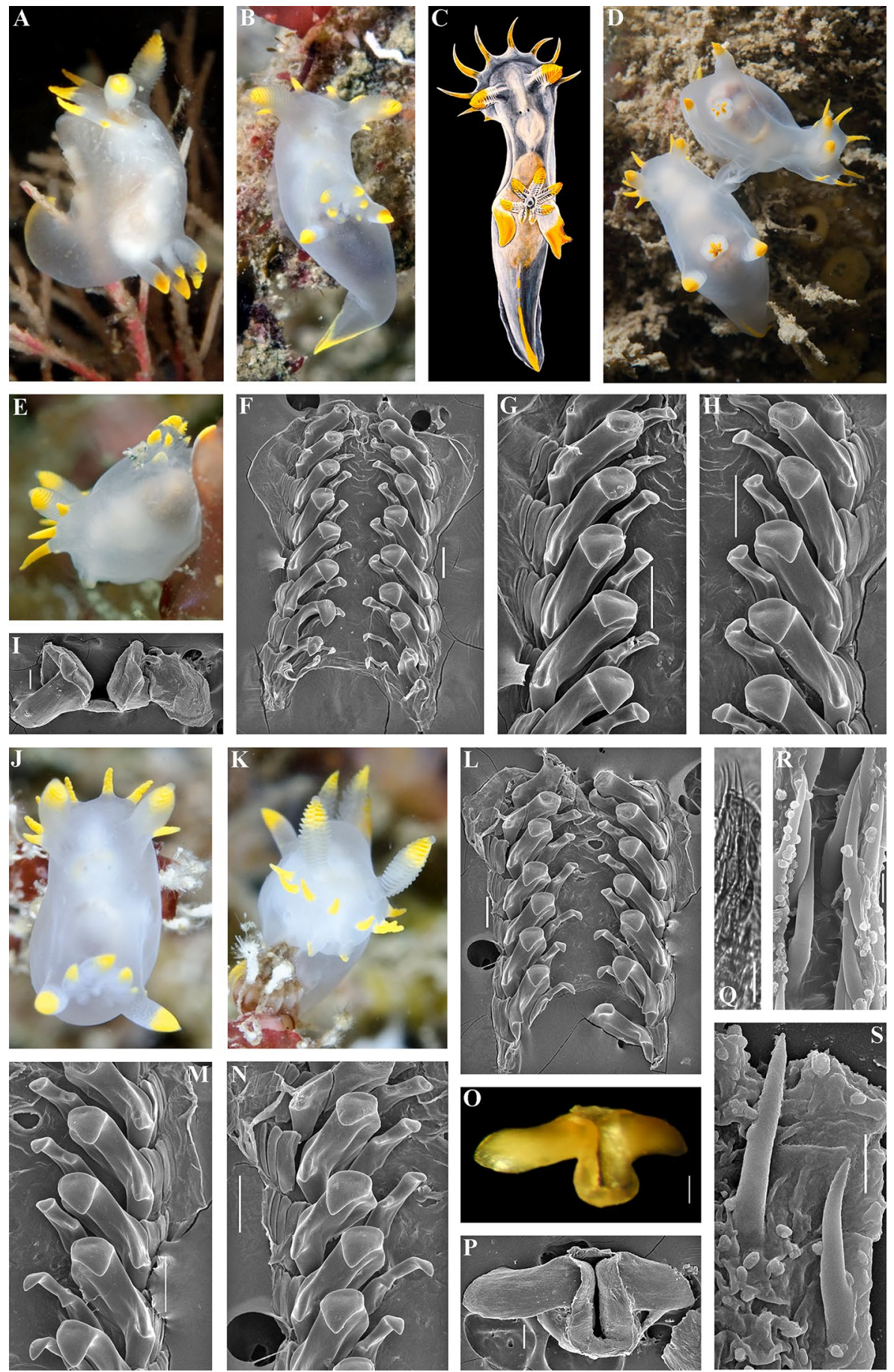

Figure 9. Polycera kernowensis sp. nov. External and internal morphology, light and scanning electron microscopy and comparison with data from Thompson and Brown ${ }^{40}$. (A) Paratype from United Kingdom, Cornwall, Porthkerris, dorsal view, live (FD 01). (B) Paratype from United Kingdom, Cornwall, Porthkerris, dorsal view, live (FD 093). (C) Specimen from United Kingdom, Skomer Island, depicted in Thompson and Brown $\left({ }^{40}: \mathrm{pl} 18, \mathrm{e}\right)$ identified as P. faeroensis but which has some features that more similar to P. kernowensis sp. nov. (D) Copulating specimens from the Great Britain, dorsal view, live. (E) Paratype from Portugal, Setubal, lateral view, live (ZMMU Op-775). (F) Radula, SEM (ZMMU Op-775). (G, H) Radula details, SEM (ZMMU Op-775). (I) Jaws, SEM (ZMMU Op-775). (J) Holotype from United Kingdom, Cornwall, Porthkerris, dorsal view, 5.6 mm, live (ZMMU Op-755). (K) Same, frontal view, live. (L) Radula of holotype, SEM. (M, N) Radula details (holotype), SEM. (O) Jaws (holotype), light microscopy. (P) Jaws (holotype), SEM. (Q) Copulative spines (holotype), light microscopy. (R, S) Copulative spines (holotype), SEM. Scale bars: f-i, $1-\mathrm{p}-100 \mu \mathrm{m}, \mathrm{q}-10 \mu \mathrm{m}$, r, s-5 $\mu$ m. Photographs: F.M.F. Driessen (a), (b), (e), (j), (k); (d) Bernard Picton. Reproduction of figure from Thompson and Brown ${ }^{40}$ with permission of Gregory Brown, original artist and copyright holder of the images. SEM micrographs and light microscopy photographs: Alexander Martynov. 


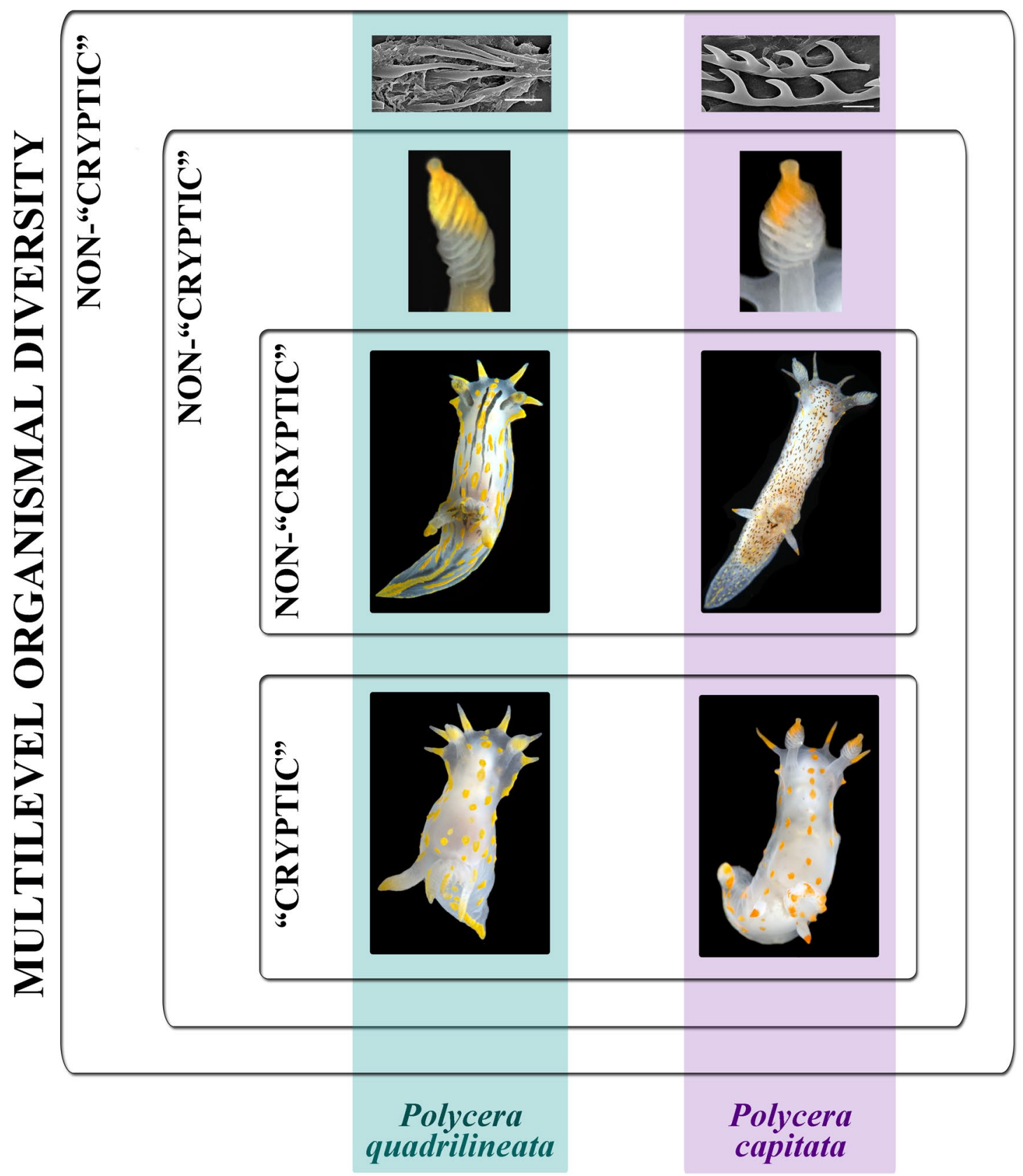

Figure 10. Presentation of the multilevel organismal diversity approach using the example of closely related Polycera quadrilineata and P. capitata: presence of conditional "non-cryptic" and putative "cryptic" components among the same species and provision of fine-scale morphological diagnostic characters even among the "cryptic component" within a single species. Scale bars- $10 \mu \mathrm{m}$.

The results of the statistical test in key diagnostic external features (number of rhinophoral lamellae, frontal veil appendages and gills) in the Polycera species complex (Fig. 2, Supplementary information S2), showed that easily accessible external morphological features are distinguishing factors among adult individuals between the species in the complex, with high statistical support (Figs. 2, Supplementary information S2, Fig. S1). Particularly, the number of the rhinophoral lamellae differs with high support among all four species (Figs. 2, 10, Supplementary information S1). It must be noted that differences in rhinophoral lamellae are partly related to the animal length, due to the fact that larger specimens may have larger numbers of rhinophoral lamellae, starting from 0 (i.e. smooth rhinophores) and reaching a mean number of lamellae towards mature stages ${ }^{43,44}$. However, even most closely related sister species $P$. quadrilineata and $P$. capitata were revealed as having smaller, but statistically significant differences in the mean number of the rhinophoral lamellae (mean 8 in P. capitata and 11-12 in P. quadrilineata) including specimens of similar sizes (Figs. 2, 10, Supplementary information S2).

The significant differences can be further used for the fine-scale diagnostics of these species. This is a very important result for further assessment of the general reliability of the "cryptic species" concept. 


\section{Discussion \\ Importance of the true, and not a formal integration of the molecular, morphological, and taxonomic data for applications in ecological and evolutionary studies. The present study is very} relevant for the investigation of the general species concept and so-called "cryptic species" concept and also for the currently commonly claimed "integration" of molecular and morphological data. It was already highlighted that the challenge represented by cryptic species has great importance for general biological problems and represents "a window into the paradigm shift of the species concept" ${ }^{20}$. We therefore present in this study the largest currently possible molecular and morphological dataset on a particular nudibranch species complex, which is widely distributed over the vast European region. Molecular data of 178 specimens belonging to four species were involved in the molecular phylogenetic analysis (Fig. 3). Furthermore, for the practitioners, and for researchers who perform environmental monitoring in the European marine waters, it is very important to trustworthily distinguish the four species, including the most difficult to distinguish $P$. quadrilineata and $P$. capitata, in the field and, above all, without complicated, time-consuming and expensive molecular analysis. This is especially important since $P$. quadrilineata complex represents an indicator of biodiversity shifts in relation to climatic changes ${ }^{27}$.

In order to develop a robust framework to make it possible to identify all four species using only easily accessible external characters and applying in the majority of cases, we hereby provide a summary of an exhaustive analysis of molecular and morphological data for all European Polycera species (Figs. 1, 2, 3, 4, $5,6,7,8,9$, Tables 1,2$)$, i.e. every newly available specimen or sequence from European waters belonging to each of the four recognized species (Fig. 3, Tables 1,2) and not to any other potential "hidden" lineages.

Polycera quadrilineata (O. F. Müller, 1776) is one of the oldest species names amongst European nudibranch molluscs ${ }^{45,46}$. Since then there were numerous attempts to separate more species similar to $P$. quadrilineata (see the Supplementary information S1 for details on the systematics of P. quadrilineata), however all of them without a detailed morphological analysis were later considered to be synonyms of $P$. quadrilineata ${ }^{40}$. Using molecular data, Driessen et al. ${ }^{21}$ showed two lineages among European " $P$. quadrilineata" for the first time. Recently one of these lineages has been formally described as Polycera norvegica ${ }^{14}$. The description proposed the species to occur exclusively in Norway. According to our data, applying a very broad geographic sampling in frames of the present study (see e.g., Figs. 3, 4) the recently named "Polycera norvegica" definitely is not distributed solely in Norway, but is a species widely distributed in other European countries, such as the United Kingdom and Ireland (Supplementary information, Table S1). Furthermore, in that publication, the numerous synonyms of $P$. quadrilineata were neither listed nor investigated, and its synonymy was just referred to the internet database MolluscaBase ${ }^{47}$.

In the present study we carefully investigated all existing available synonyms of P. quadrilineata (Figs. 1, 2, 3, 4, 5, 6, 7, Table 1, Supplementary information Fig. S1). Therefore, being part of the difficult to distinguish P. quadrilineata complex, for which more than ten synonyms have been suggested, and having a broad distribution in Europe, "P. norvegica" could have already been described. If "P. norvegica" had no clear recognizable chromatic variants which immediately distinguished it from $P$. quadrilineata it would be difficult to assess a potential synonym. However, "darker" chromatic variants (Fig. 1IV-VII) are clearly different between $P$. quadrilineata and "P. norvegica", which makes a solid base for the search for such previously described variants within taxonomic synonyms. During this study we identified two available taxonomic names that contain chromatic variants with darker colouration without evident stripes, and those can be thus excluded from the striped variants of true P. quadrilineata (Figs. 1, 2, 5, 7). These available names are Polycera ornata d'Orbigny, 1837 and Thecacera capitata Alder \& Hancock, 1854. For Polycera ornata a main morph with red-orange lines was described ${ }^{48}$ and in addition a morph with weaker orange and black spots was mentioned. Because of a main morph with orange-reddish lines in Polycera ornata, and having only an old painting published, it is difficult to surely distinguish the morph from $P$. quadrilineata. Furthermore, for P. ornata a "tiger-like" colouration was indicated for the darker morph ${ }^{48}$, that may imply stripes, as in true P. quadrilineata. Thus, to assign Polycera ornata to this species would be ambiguous. Also, the type material of Polycera ornata was not saved.

Instead, for Thecacera capitata in the original description by Alder \& Hancock (1854) the colouration was solely indicated as "freckled with brownish greenish" 49 that immediately allows exclusion of any morphs with evident black stripes, that are present only in true P. quadrilineata (Figs. 1, 5). Thecacera capitata was later confirmed as belonging to the genus Polycera and not to Thecacera, including study of the type material ${ }^{40}$; presence of rhinophoral sheaths for P. capitata was thus indicated mistakenly ${ }^{49}$. Polycera capitata was partly redescribed with aid of the type material regarding external features and the external colouration ${ }^{40}$ and exactly matched the chromatic variant $\mathrm{V}$ in $P$. norvegica but not any chromatic variants of $P$. quadrilineata (Figs. 1, 7M). In this study we additionally studied the saved radula from the type specimen of Polycera capitata as was figured in the original description ${ }^{49}$. The radula has only four outer lateral teeth and thus fits well to the most rigorous assessment of the radular characters in this species, including "P. norvegica"14.

This combination of the external and internal data excludes the possibility that Polycera capitata is a synonym of $P$. quadrilineata but instead conforms closely to the characters that were recently described for P. norvegica ${ }^{14}$. We have involved numerous specimens from the United Kingdom and Ireland-that matched well morphologically to the original description of $P$. capitata (Figs. 1, 7) -in the present molecular analysis. The present study shows that darker chromatic variants V-VII without distinct stripes are characteristic solely for $P$. capitata (Figs. 1, 7, 10). Furthermore, these darker chromatic variants of $P$. capitata are very common throughout the United Kingdom from Cornwall in the south to the Scotland in the north, including the type locality at St. Ives, Cornwall according to the available photographic data ${ }^{50,51}$. 
These data were already available, but an essential external similarity of " $P$. norvegica" to $P$. capitata was missed and it was incorrectly stated that the species is restricted to Norway ${ }^{14}$. "P. norvegica" syn. nov. thus becomes a junior synonym of Polycera capitata. Additionally, (with permission) we present a copy of plate $18 \mathrm{c}$ from Thompson \& Brown (1984) ${ }^{40}$ where the external features illustrated for Polycera capitata correspond exactly with our morphological data for P. capitata (Fig. 7M). Therefore, our present taxonomic assignment of $P$. capitata is robustly supported by the abundant morphological (including statistical study), molecular and distributional data (Figs. 1, 2, 3, 4, 5, 6, 7, Table 1, Supplementary information, Table S1, Fig. S1). In the present study we therefore restore the species $P$. capitata and $P$. norvegica becomes its junior synonym.

Importantly, what appears to be a particular taxonomic problem, has in reality general importance for an array of biological fields since it clearly shows that without true integration of an "old" taxonomic knowledge, that tends to be neglected currently, with modern morphological and molecular data, an appropriate study of world biodiversity cannot be performed. The "cryptic species problem" therefore does not emerge only recently, but was always part of taxonomy since the Linnean era. A formal integration of the molecular and morphological data and inaccurate claim for "cryptic species" led to omission of a synonym for a common, species which is important for ecological monitoring. Therefore, the importance of true and not just a formal integration of molecular, morphological and taxonomic data are here specially highlighted and a practical set of methods is proposed below.

Periodic-like framework for the recognition diagnosable characters in the species complexes. Periodic-like as well as parallel-like patterns in biological applications have been discussed for a long time and successfully applied for protein structure ${ }^{52}$, but they are still not widely used practical tools for taxonomy and phylogeny. Several recent studies on different groups, such as rodents ${ }^{53}$ and fishes ${ }^{54,55}$ robustly confirmed the existence of periodic patterns during development of morphological characters at a genomic level, particularly concerning chromatic variants and thus are directly connected with the present Polycera case. Notably, the ontogenetic periodicity is based on periodicity of homeobox and other developmental gene systems in animals and plants ${ }^{56,57}$, thus approaching chemical periodicity. Recently an evident periodicity was revealed for a higher-level organism group using an ontogenetic phylotypic periods/stages approach, that consistently links the genomic and morphological levels ${ }^{44}$. There were attempts to describe chromatic variants within another nudibranch family Chromodorididae under the term "colour groups" 58 or as different colour morphs in frames of a phylogeny ${ }^{59,60}$, but not in a periodic framework. However, when similar morphs of different closely related species are mapped in the same horizontal sections, the partial periodicity can be clearly revealed ${ }^{18}$.

During individual development, this was investigated for Polycera quadrilineata ${ }^{36}$, the darker colouration appeared during later stages of the ontogeny, and similar patterns of the ontogeny of the sister species $P$. capitata must present in parallel, which makes the biological grounds for the periodic-like approach. Such an approach is a practical one and helps to reveal fine distinguishing details among apparently very similar morphs (e.g. chromatic variants) and also potentially not yet discovered morphs of the closely related species. Currently we have no information about which particular genes underlie any common genetic basis in the polychromatic nudibranchs ${ }^{61}$, but it must inevitably imply similar developmental genes basis and it was recently used for delineation of a very difficult nudibranch species complex of the genus Amphorina ${ }^{18}$. A North Pacific species, Polycera atra MacFarland, 1905, provides evidence for the existence of the underlying similar genomic basis, that appears in parallel in various phylogenetic lineages. According to the present analysis it represents a taxon which is only distantly related to the $P$. quadrilineata complex (Fig. 3), and potentially may belong to a separate genus (a general revision of the family Polyceridae is pending), but nevertheless exhibits similar chromatic variants ${ }^{62}$. As in the $P$. quadrilineata complex, about eight chromatic variants of $P$. atra are recognized. These are used in the present study to align the chromatic variants found within the European Polycera species (Fig. 1). Such parallel appearance of the similar chromatic variations in relatively distantly related clades is well matched to the parallel appearance of the shell morphs within gastropod molluscs ${ }^{63}$, for which a similar genomic base has already been confirmed ${ }^{64}$.

The present Polycera chromatic polymorphism is a clear case of periodic appearance of similar colour morphs among phylogenetically related but different species which has robust support from a large molecular dataset (Figs. 1,3). Polycera quadrilineata also possesses stripe patterns in their colouration (Fig. 1V-VIII), and similar patterns were recently showed as underlain by ontogenetic periodicity in various groups ${ }^{54,55}$. Within $P$. capitata instead darker forms (Fig. 1V-VIII) appear in parallel, without distinct stripes, but with remnants of a faint stripe-like pattern (Fig. 1VI). In both P. faeroensis and P. kernowensis sp. nov. the chromatic variants IV-VII are not yet discovered (Fig. 1). This makes the method a practical tool for revealing a diagnosable character within putative "cryptic species complexes". While biologists from non-taxonomic fields or experienced practitioners have the task to identify Polycera in the field, they will be guided by a periodic-like mapping (Fig. 1) which is based on accurate taxonomy and robust molecular phylogenetic data (Figs. 3, 4). It will be easier to exclude these variants that do not occur (as striped or heavily spotted variants are not yet found in P. faeroensis and P. kernowensis sp. nov.), and instead carefully investigate similar chromatic variants II and III in two sister species P. quadrilineata and P. capitata (Fig. 1).

When such periodic-like mapping becomes a routine part of biodiversity studies, the accumulated data will allow the presentation of small, fine-scale distinguishing characters even between such highly similar orange-spotted chromatic variants that are present in both P. quadrilineata and P. capitata. At 
present, they remain difficult to distinguish, but using available data we can preliminarily conclude that in $P$. capitata orange spots are more commonly smaller and more rarely form lines, than in P. quadrilineata (Figs. 1, 2, 5, 7). A statistical test of the diagnostic value of the external characters, that were mapped in the periodic-like framework, revealed that number of the rhinophoral lamellae, though it may overlap in juvenile specimens, in adult specimens is different with a statistical high support including among these difficult to distinguish chromatic variants II and III between P. capitata and P. quadrilineata (Fig. 2, Supplementary information S1, Fig. S1). Thus, the number of the rhinophoral lamellae (a very easy to check character even on the photographs), can be used as an additional verification in case of similar chromatic variants II and III between $P$. capitata (commonly less than ten rhinophoral lamellae in adults) and $P$. quadrilineata (commonly more than ten rhinophoral lamellae in adults).

The periodic-like mapping of the chromatic variants revealed that orange dots on the body sometimes occur, as well as potentially darker morphs in true P. faeroensis (Fig. 1II-VIII), but patterns and quantity differ between P. quadrilineata and P. capitata (Fig. 1II-VIII). Previously all four species of the European Polycera complex have been confused with each other ${ }^{40,65}$ also because these chromatic variants were previously never accurately mapped with each other, but instead it was commonly noted that similar to $P$. quadrilineata and $P$. capitata yellow-orange dots were sometimes present on the body in P. faeroensis, which immediately misled practitioners that have had tasks to identify animals in the field. Further, this profound confusion among identification of European Polycera persists even using modern molecular tools as $P$. faeroensis until the present study was not distinguished from P. kernowensis sp. nov., despite the presence of robust external, internal, and molecular differences (Figs. 1, 2, 3, $4,8,9)$. Thus, the periodic-like mapping of the polychromatic variants in combination with statistical analysis of the diagnostic characters is an important tool in addition to the molecular phylogenetic analysis. It will be particularly important since $P$. quadrilineata and $P$. capitata are two of the most common nudibranch species in Europe, and particularly in the UK the further testing of their chromatic variance already attracted attention ${ }^{51}$ and further attraction of various environmental and educational organizations and citizen scientists is expected. Our present study builds a major framework for further broader testing of the colour polymorphism and other distinguishing features in the Polycera species complex that will have importance for the development of documenting the fine-scale diversity not only in other nudibranchs, but in the variety of multicellular organisms.

Practical guidelines how to perform a taxonomic study in the molecular era. The present study evidently shows that "cryptic" and "non-cryptic" components are present within the same species. This further significantly undermines the "cryptic species" concept, which recently was already questioned $^{4,10-12}$. The presence of both "cryptic" and "non-cryptic" components is demonstrated here for sister species $P$. quadrilineata and P. capitata sharing externally similar chromatic variants II and III (Fig. 1), which however can be distinguished by the morphological features of another level (Figs. 5, 7). Particularly, the internal features of the shape and size of copulative spines allow in $100 \%$ cases to confirm the identity of both species (compare Figs. 5K, L, Q, R, V-X and 7E, F, L, R, S, W-Z), even without aid of molecular data this undermines the proposal that these species are morphologically "cryptic". In our recent study ${ }^{12}$ we already showed how the underestimation of the taxonomic and morphological data resulted in a long-term omission of reliable multilevel differences in the nudibranch Trinchesia species complex. Recently, there are proposals that taxonomy should be an integrative study ${ }^{66-68}$. However, in current common practice "integration" unfortunately mainly means performing a molecular study on some selection of specimens and then morphological features listed "in addition", rather as an auxiliary information. The best confirmation of this is the recent Polycera study ${ }^{14}$, when crucial previous taxonomic information was omitted, and while some morphological diagnostic features were revealed, both their stability and variability (and hence, their usefulness for taxonomic diagnostics) were over- or underestimated that subsequently led to an incorrect statement about "general crypticity" of the involved species.

To avoid this, practical guidelines proposing how to perform a taxonomic study in the molecular era are outlined here: (1) make a selection of a taxonomic group and appropriate specimens; (2) make a relevant morphological study in a given group, including for example scanning electron microscopy of previously commonly used diagnostic characters in the given group; (3) ensure that ontogenetic information is considered during taxonomic assessment, because adult diagnostic characters can be considerably transformed at different ontogenetic stages, whereas adult paedomorphic characters can be easily misidentified with juvenile transitive features ${ }^{44,69-71}$; (4) make an appropriate bibliographic study, to exhaustively study the synonymy of a studied taxa/species group, importantly, not just as a reference to a taxonomic data base, but to perform a real study of original sources; (5) molecular study selected and taxonomically checked specimens with commonly used genetic markers in a given group; (6) compare the results of the morphological (step 2) and taxonomic investigation (steps 3,4) with the molecular (step 5) results; (7) in case of finding discrepancies between previously commonly assessed diagnostic characters in a given species group and results of molecular phylogeny, respective diagnostic features of specimens in question should be presented in a periodic-like framework of the parallel rows, that will enable their detailed comparison and further search for fine-scale differences between given rows for each of the closely related species; (8) in case difficult to distinguish variants are present among the same parallel rows, a statistic study of the relevant diagnostic features should be performed in order to reveal fine-scale differences among closely related species; (9) a complete study at a given time and using current research possibilities should result in fine-scale taxonomic diagnoses for all closely related species in a given taxa/complex (including new taxa); (10) test the established framework by further investigation of a given group with new materials and data.

Applying the above described methodology and using a large dataset we were able to exhaustively investigate the European Polycera species complex (Figs. 1, 2, 3, 4) which was recently specially termed 
as a "cryptic one"14. As a result, we definitely assessed every particular specimen (or sequence data) to a particular species: P. quadrilineata, P. capitata, P. faeroensis, and P.kernowensis sp. nov. (Figs. 1, 3, 5, 9). For each of these species we provided diagnostic characters that are based not just on traditional taxonomic "listing" of some features, but on statistically supported analysis of key external features. Particularly, in addition to the molecular phylogenetic study and periodic-like mapping of the chromatic variance we tested the most commonly used diagnostic characters within the Polycera species complex, such as number of the rhinophoral lamellae, number of frontal veil appendages and number of gills using statistical tests (Fig. 2). As a result, we discovered that the four species differ in number of rhinophoral lamellae with high statistical support (Fig. 2, Supplementary information S2). With this study, we integrated molecular and morphological data and moreover recovered the multilevel diagnosable diversity within the given species complex, including presenting the distinguishing characteristics between closely related and most difficult to distinguish species from this complex: P. quadrilineata and P. capitata. When specimens of these species belong to similar chromatic variants II and III, it will be possible to diagnose it using not only clearly different micromorphological features of copulative spines, but also easily accessible external morphological features (Figs. 2, 5, 7, Supplementary information, Fig. S1). They possess consistent molecular and morphological units, and importantly, there are no signs for further hidden molecular lineage among European Polycera species.

Multilevel organismal diversity approach and conclusions on "cryptic species" problem. According to the suggested approach, when knowing more difficult to distinguish species within a species-complex in other organism groups $s^{8,12,72}$, putative crypticity means that characteristics were not investigated at a maximally possible fine-scale level (despite considerable efforts) using fine morphologybased comparative rows of parallel characteristics. Without comparative rows of parallel characters it is especially difficult to distinguish species with a highly simplified morphology, for example tiny paedomorphic, decelerated burrowing polychaete worms ${ }^{13,73}$. Using a lineage-based approach, as shown recently ${ }^{1}$, is not enough for species definition. Every new specimen, even a clone must have either smaller or larger differences from any other specimens ${ }^{12}$. It is therefore biologically impossible that a species can be morphologically "completely cryptic". Conclusions about a "cryptic species" appeared when fine-scale differences (either macro- or micromorphological) were not detected at a present level of knowledge in given groups. It was already concluded most recently that in several cases, potential diagnostic characters were hidden within broadly overestimated "intraspecific variations" 14 and that a search for the fine-scale morphological differences using various modern methods is important part of future research, because otherwise, for example in palaeontology, species diagnostics will be greatly compromised ${ }^{74}$.

The present data evidently imply that both $P$. quadrilineata and $P$. capitata species comprise putative "cryptic" and conditional "non-cryptic" components. We generated a scheme to clearly show this phenomenon (Fig. 10). P. quadrilineata and P. capitata have similar chromatic variants (Fig. 1II-III, 10) at a "macromorphological" level. Therefore they conditionally represent a "cryptic component" but are readily different by other chromatic variants (IV-VIII). This additionally has a strong statistical support in other external macromorphological features, such as the number of rhinophoral lamellae, and therefore manifesting a "non-cryptic component" for the diversity within Polycera (Figs. 2, 10). Subsequently, at a "micromorphological" level, the differences in shape and size of the copulative spines allow clear and unambiguous distinction of $P$. quadrilineata and P. capitata by "non-cryptic components" (Fig. 10). Further, at a molecular level all four Polycera species demonstrate significant genetic distances (Figs. 3, 4; Table 2).

Particularly, the special emphasising about "crypticity" of P. capitata in Norway ${ }^{14}$ did not help to correctly recognize taxonomic and distributional data for this species, but instead led to important omission that in reality P. capitata is not restricted to Norway, but common throughout waters of the middle and Northern Europe (Figs. 3, 4; Supplementary information Table S1). By results of the present study, we can further extend and strengthen our recent arguments ${ }^{4,12}$ and conclude that it is highly counterproductive to divide the biological diversity into "cryptic", 14,75 and "non-cryptic" components since both may be presented within a single species. Additionally, the term "cryptic species" can be misleading because of its continued usage in recent publications, but in a completely different ecological meaning of a well camouflaged species ${ }^{76,77}$.

We propose that the central biological phenomenon of a species that currently attempted to be disrupted into "cryptic" and "non-cryptic" ones can be instead universally designated as multilevel organismal diversity (Fig. 10). This term will avoid artificial division of the very complex biological phenomenon of diversity. Multilevel organismal diversity encompasses numerous patterns and processes of various levels, from which most notable and readily recognizable are morphological and molecular levels, each with numerous intersected sublevels, ultimately forming complex functional living organisms.

\section{Data availability}

Sequences will be deposited in GenBank, and can be consulted accessing GenBank, with sequence IDs listed in Table S1.

Received: 22 February 2021; Accepted: 30 June 2021

Published online: 15 September 2021

\section{References}

1. Freudenstein, J. V., Broe, M. B., Folk, R. A. \& Sinn, B. T. Biodiversity and the species concept-Lineages are not enough. Syst. Biol. 66, 644-656. https://doi.org/10.1093/sysbio/syw098 (2017). 
2. Zachos, F. E. Species Concepts in Biology. Historical Development, Theoretical Foundations and Practical Relevance (Springer Nature Switzerland, 2016).

3. Stanton, D. et al. More grist for the mill? Species delimitation in the genomic era and its implications for conservation. Conser. Gen. 20, 101-113. https://doi.org/10.1007/s10592-019-01149-5 (2019).

4. Korshunova, T. A., Bakken, T., Grøtan, V. V., Johnson, K. B. \& Martynov, A. V. A synoptic review of the family Dendronotidae (Mollusca: Nudibranchia): A multilevel organismal diversity approach. Contr. Zool. https://doi.org/10.1163/18759866-BJA10014 (2020).

5. Jamie, G. A. \& Meier, J. I. The persistence of polymorphisms across species radiations. Trends Ecol. Evol. https://doi.org/10.1016/j. tree.2020 (2020).

6. Mayr, E. Systematics and the Origin of Species (Columbia University Press, 1942).

7. David, J. R. \& Bocquet, C. Similarities and differences in latitudinal adaptation of two Drosophila sibling species. Nature 257, 588-590. https://doi.org/10.1038/257588a0 (1975).

8. Saéz, A. G. \& Lozano, E. Body doubles. Nature 433, 111. https://doi.org/10.1038/433111a (2005).

9. Alves, P. V., de Chambrier, A., Luque, J. L. \& Scholz, T. Integrative taxonomy reveals hidden cestode diversity in Pimelodus catfishes in the Neotropics. Zool. Scr. https://doi.org/10.1111/zsc.12465 (2020).

10. Heethoff, M. Cryptic species-Conceptual or terminological chaos?. Trends Ecol. Evol. 33, 310. https://doi.org/10.1016/j.tree.2018. 02.006 (2018).

11. Horsáková, V., Nekola, J. C. \& Horsák, M. When is a "cryptic" species not a cryptic species: A consideration from the Holarctic micro-land snail genus Euconulus (Gastropoda: Stylommatophora). Mol. Phyl. Evol. 132, 307-320. https://doi.org/10.1016/j.ympev. 2018.12.004 (2019).

12. Korshunova, T. et al. Multilevel fine-scale diversity challenges the 'cryptic species' concept. Sci. Rep. 9, 6732. https://doi.org/10. 1038/s41598-019-42297-5 (2019).

13. Cerca, J., Meyer, C., Purschke, G. \& Struck, T. H. Delimitation of cryptic species drastically reduces the geographical ranges of marine interstitial ghost-worms (Stygocapitella; Annelida, Sedentaria). Mol. Phyl. Evol. 143(106663), 1-16. https://doi.org/10. 1016/j.ympev.2019.106663 (2020).

14. Sørensen, C. G., Rauch, C., Pola, M. \& Malaquias, M. Integrative taxonomy reveals a cryptic species of the nudibranch genus Polycera (Polyceridae) in European waters. J. Biol. Assoc. UK https://doi.org/10.1017/S0025315420000612 (2020).

15. Marchán, D. F., Fernández, R., Domínguez, J., Díaz Cosín, D. J. \& Novo, M. Genome-informed integrative taxonomic description of three cryptic species in the earthworm genus Carpetania (Oligochaeta, Hormogastridae). Syst. Biodiv. 18, 203-215. https://doi. org/10.1080/14772000.2020.1730474 (2020).

16. Hinojosa, J. C. et al. Rapid colour shift by reproductive character displacement in Cupido butterflies. Mol. Ecol. https://doi.org/10. $1111 /$ mec.15682 (2020).

17. Ruiz, M. B., Taverna, A., Servetto, N., Sahade, S. \& Held, C. Hidden diversity in Antarctica: Molecular and morphological evidence of two different species within one of the most conspicuous ascidian species. Ecol. Evol. 10, 8127-8143. https://doi.org/10.1002/ ece3.6504 (2020).

18. Korshunova, T. et al. Fine-scale species delimitation: Speciation in process and periodic patterns in nudibranch diversity. ZooKeys 917, 15-50. https://doi.org/10.3897/zookeys.917.47444 (2020).

19. Haase, M., Meng, S. \& Horsák, M. Tracking parallel adaptation of shell morphology through geological times in the land snail genus Pupilla (Gastropoda: Stylommatophora: Pupillidae). Zool. J. Linn. Soc. https://doi.org/10.1093/zoolinnean/zlaa057 (2020).

20. Fišer, C., Robinson, C. T. \& Malard, F. Cryptic species as a window into the paradigm shift of the species concept. Mol. Ecol. 27, 613-635. https://doi.org/10.1111/mec.14486 (2018).

21. Driessen, F.M.F., Dekker, R., Luttikhuizen, P. \& van Bleijswijk, J. Taxonomic identity of representatives of the nudibranch genus Polycera in Dutch coastal waters. Master research report, University of Groningen \& Royal Netherlands Institute for Sea Research. http://fse.studenttheses.ub.rug.nl/id/eprint/11989. (2014).

22. Martínez-Pita, I., Sánchez-España, A. I. \& García, F. J. Some aspects of the reproductive biology of two Atlantic species of Polycera (Mollusca: Opisthobranchia). J. Mar. Biol. Assoc. UK 86, 391-399. https://doi.org/10.1017/S0025315406013245 (2006).

23. Lock, K., Newman, P., Burton, M. \& Jones, J. Skomer marine conservation zone nudibranch diversity survey. Nat. Resources Wales Rep. 321, 1-62 (2018).

24. Pratt, M. C. \& Grason, E. W. Invasive species as a new food source: Does a nudibranch predator prefer eating an invasive bryozoan?. Biol. Invas. 9, 645-655. https://doi.org/10.1007/s10530-006-9065-x (2007).

25. Picton, B. E. \& Morrow, C. A Field Guide to the Nudibranchs of the British Isles (Immel Publishing, 1994).

26. Tullrot, A. The evolution of unpalatability and warning coloration in soft-bodied marine invertebrates. Evolution 48, 925-928. https://doi.org/10.1111/j.1558-5646.1994.tb01374.x (1994).

27. Martynov, A. V., Korshunova, T. A. \& Savinkin, O. V. Shallow-water opisthobranch molluscs of the Murman coast of the Barents Sea, with new distributional data and remarks on biology. Ruthenica 16, 59-72 (2006).

28. Bellard, C., Bertelsmeier, C., Leadley, P., Thuiller, W. \& Courchamp, F. Impacts of climate change on the future of biodiversity. Ecol. Lett. 15(365-377), 2012. https://doi.org/10.1111/j.1461-0248.2011.01736.x (2012).

29. Korshunova, T. A., Martynov, A. V., Bakken, T. \& Picton, B. E. External diversity is restrained by internal conservatism: New nudibranch mollusc contributes to the cryptic species problem. Zool. Scr. 46, 683-692. https://doi.org/10.1111/zsc.12253 (2017).

30. Katoh, K., Misawa, K., Kuma, K. \& Miyata, T. MAFFT: A novel method for rapid multiple sequence alignment based on fast Fourier transform. Nucleic Acids Res. 30, 3059-3066. https://doi.org/10.1093/nar/gkf436 (2002).

31. Nylander, J. A., Ronquist, F., Huelsenbeck, J. P. \& Nieves-Aldrey, J. L. Bayesian phylogenetic analysis of combined data. Syst. Biol. 53, 47-67 (2004).

32. Ronquist, F. et al. MrBayes 3.2: Efficient Bayesian phylogenetic inference and model choice across a large model space. Syst. Biol. 61, 539-542. https://doi.org/10.1093/sysbio/sys029 (2012).

33. Stamatakis, A., Hoover, P. \& Rougemont, J. A rapid bootstrap algorithm for the RAxML web servers. Syst. Biol. 75, 758-771. https:// doi.org/10.1080/10635150802429642 (2008).

34. Kumar, S., Stecher, G. \& Tamura, K. MEGA7: Molecular evolutionary genetics analysis version 7.0 for bigger datasets. Mol. Biol. Evol. 33, 1870-1874. https://doi.org/10.1093/molbev/msw054 (2016).

35. Puillandre, N., Lambert, A., Brouillet, S. \& Achaz, G. ABGD, Automatic barcode gap discovery for primary species delimitation. Mol. Ecol. 21, 1864-1877. https://doi.org/10.1111/j.1365-294X.2011.05239.x (2011).

36. Haefelfinger, H. R. Beobachtungen an Polycera quadrilineata (Müller) (Moll., Nudibr.). Rev. Suis. Zool. 67, 101-117 (1960).

37. Korshunova, T. A. et al. Polyphyly of the traditional family Flabellinidae affects a major group of Nudibranchia: aeolidacean taxonomic reassessment with descriptions of several new families, genera, and species (Mollusca, Gastropoda). ZooKeys 717, 1-139. https://doi.org/10.3897/zookeys.717.21885 (2017).

38. Muniain, C. \& Ortea, J. The taxonomic status and redescription of Polycera marplatensis Franceschi, 1928 (Nudibranchia: Polyceratidae) from Argentina. Veliger 41, 142-147 (1998).

39. Lemche, H. M. \& Thompson, T. E. Three opisthobranch gastropods new to the British fauna. Proc. Mal. Soc. Lond. 41, 185-193. https://doi.org/10.1093/oxfordjournals.mollus.a065268 (1974).

40. Thompson, T. E. \& Brown, G. H. Biology of Opisthobranch Molluscs Vol. 3 (The Ray Society Publications, 1984).

41. Lemche, H. Gastropoda opisthobranchiata. In: R. Sparck \& S. L. Tuxen (Eds.). Zool. Faroes, 3, 1-35. (1929). 
42. Odhner, N. New polycerid nudibranchiate Mollusca and remarks on this family. Göteborgs Kungl. Veten. Vitt. Sam. Handl Ser. B 3, 1-20 (1941).

43. Thompson, T. E. The natural history, embryology, larval biology and post-larval development of Adalaria proxima (Alder and Hancock) (Gastropoda Opisthobranchia). Phil Trans. Roy. Soc. Lond. Series B 242, 1-58. https://doi.org/10.1098/rstb.1958.0012 (1958).

44. Martynov, A. V. \& Korshunova, T. A. A new deep-sea genus of the family Polyceridae (Nudibranchia) possesses a gill cavity, with implications for the cryptobranch condition and a 'Periodic Table' approach to taxonomy. J. Moll. Stud. 81, 365-379. https://doi. org/10.1093/mollus/eyv003 (2015).

45. Müller, O. F. Zoologiae Danicae. Prodromus seu animalium Daniae et Norvegiae. (Hallageriis, Copenhagen, 1776).

46. Bergh, R. Beiträge zu einer Monographie der Polyceraden I. Verhandlunge Kaiserliche Königliche Zoologische Botanischen Gesellschaft Wien 29, 599-652 (1879).

47. Molusca Base. Polycera Cuvier, 1816. Accessed through: World Register of Marine Species at. http://www.marinespecies.org/aphia. php? $\mathrm{p}=$ taxdetails\&id=138369. (Accessed 04 September 2020).

48. D’Orbigny, A. Mémoire sur des espèces et sur des genres nouveaux de l’ordre des nudibranches, observés sur les côtes de France. Guer. Mag. Zool. 7, 1-16 (1837).

49. Alder, J. \& Hancock, A. Notice of some new species of British Nudibranchiata. Ann. Mag. Nat. Hist. 14, 102-105. https://doi.org/ $10.1080 / 037454809494312$ (1854).

50. Anderson, J. \& Picton, B. Scottish Nudibranchs (Kindle Edition, 2017).

51. Fenwick, D. An educational resource to the diversity of marine life of Great Britain and Ireland. https://www.aphotomarine.com/. (2020).

52. Taylor, W. R. A 'periodic table' for protein structures. Nature 416, 657-660. https://doi.org/10.1038/416657a (2002).

53. Johnson, M. R., Barsh, G. S. \& Mallarino, R. Periodic patterns in Rodentia: Development and evolution. Exp. Derm. 28, 509-513. https://doi.org/10.1111/exd.13852 (2019).

54. Gante, H. F. How fish get their stripes-Again and again. Science 362, 396-397. https://doi.org/10.1126/science.aav3373 (2018).

55. Salis, P., Lorin, T., Laudet, V. \& Frédérich, B. Magic traits in magic fish: Understanding color pattern evolution using reef fish. Trends Gen. 35, 265-278. https://doi.org/10.1016/j.tig.2019.01.006 (2019).

56. Holland, P. W. H. Evolution of homeobox genes. WIREs Dev. Biol. 2, 31-45. https://doi.org/10.1002/wdev.78 (2013).

57. Smaczniak, C., Immink, R. G. H. \& Angenent, G. C. Developmental and evolutionary diversity of plant MADS-domain factors: Insights from recent studies. Development 139, 3081-3098. https://doi.org/10.1242/dev.074674 (2012).

58. Rudman, W. B. The Chromodorididae (Opisthobranchia: Mollusca) of the Indo-West Pacific: A review of the genera. Zool. J. Linn. Soc. 81, 115-273. https://doi.org/10.1111/j.1096-3642.1984.tb01174.x (1984).

59. Padula, V. et al. A test of color-based taxonomy in nudibranchs: Molecular phylogeny and species delimitation of the Felimida clenchi (Mollusca: Chromodorididae) species complex. Mol. Phyl. Evol. 103, 215-229. https://doi.org/10.1016/j.ympev.2016.07. 019 (2016).

60. Layton, K., Gosliner, T. \& Wilson, N. Flexible colour patterns obscure identification and mimicry in Indo-Pacific Chromodoris nudibranchs (Gastropoda: Chromodorididae). Mol. Phyl. Evol. 124, 27-36. https://doi.org/10.1016/j.ympev.2018.02.008 (2018).

61. Cheney, K. L. et al. Choose your weaponry: Selective storage of a single toxic compound, Latrunculin A, by closely related nudibranch molluscs. PLoS ONE 11, e0145134. https://doi.org/10.1371/journal.pone.0145134 (2016).

62. Santander, M. \& Valdés, A. Genetic structure of Polycera alabe and P. atra (Mollusca: Opistobranchia: Nudibranchia) in the Pacific coast of North America. Bull. S. Calif. Acad. Sci. 112, 176-184. https://doi.org/10.3160/0038-3872-112.3.176 (2013).

63. Davison, A., Jackson, H. J., Murphy, E. W. \& Reader, T. Discrete or indiscrete? Redefining the colour polymorphism of the land snail Cepaea nemoralis. Heredity 123, 162-175. https://doi.org/10.1038/s41437-019-0189-z (2019).

64. Neiber, M. T. \& Hausdorf, B. Molecular phylogeny reveals the polyphyly of the snail genus Cepaea (Gastropoda: Helicidae). Mol. Phyl. Evol. 93, 143-149. https://doi.org/10.1016/j.ympev.2015.07.022 (2015).

65. Just, H. \& Edmunds, M. North Atlantic nudibranchs (Mollusca) seen by Henning Lemche, with additional species from the Mediterranean and the north east Pacific. Ophelia Suppl. 2, 1-170 (1985).

66. Dayrat, B. Toward integrative taxonomy. Biol. J. Linn. Soc. 85, 407-415. https://doi.org/10.1111/j.1095-8312.2005.00503.x (2005).

67. Heethoff, M., Laumann, M., Weigmann, G. \& Raspotnig, G. Integrative taxonomy: Combining morphological, molecular and chemical data for species delineation in the parthenogenetic Trhypochthonius tectorum complex (Acari, Oribatida, Trhypochthoniidae). Front. Zool. 8, 2 https://doi.org/10.1186/1742-9994-8-2 (2011).

68. Schlick-Steiner, B. C. et al. Integrative taxonomy: A multisource approach to exploring biodiversity. Annu. Rev. Ent. 55, 421-438. https://doi.org/10.1146/annurev-ento-112408-085432 (2010).

69. Martynov, A. et al. Multiple paedomorphic lineages of softsubstrate burrowing invertebrates: Parallels in the origin of Xenocratena and Xenoturbella. PLoS ONE 15, e0227173. https://doi.org/10.1371/journal.pone.0227173 (2020).

70. Korshunova, T. et al. The Emperor Cadlina, hidden diversity and gill cavity evolution: New insights for the taxonomy and phylogeny of dorid nudibranchs (Mollusca: Gastropoda). Zool. J. Linn. Soc. 189, 762-827. https://doi.org/10.1093/zoolinnean/zlz126 (2020).

71. Lamsdell, J. C. A new method for quantifying heterochrony in evolutionary lineages. Paleobiology https://doi.org/10.1017/pab. 2020.17 (2020).

72. Golestani, H. et al. The little Aplysia coming of age: From one species to a complex of species complexes in Aplysia parvula (Mollusca: Gastropoda: Heterobranchia). Zool. J. Linn. Soc. 187, 279-330. https://doi.org/10.1093/zoolinnean/zlz028 (2019).

73. Cerca, J. et al. Deceleration of morphological evolution in a cryptic species complex and its link to paleontological stasis. Evolution 74, 116-131. https://doi.org/10.1111/evo.13884 (2020).

74. Brochu, C. A. \& Sumrall, C. D. Modern cryptic species and crocodylian diversity in the fossil record. Zool. J. Linn. Soc. 189, 700-711. https://doi.org/10.1093/zoolinnean/zlaa039 (2020).

75. Bonomo, L. J. \& Gosliner, T. M. Adding stars to the Chromodoris (Nudibranchia, Chromodorididae) galaxy with the description of four new species. Zootaxa https://doi.org/10.11646/zootaxa.4819.3.1 (2020).

76. Vine, S. J. et al. Comparison of methods to detect rare and cryptic species: A case study using the red fox (Vulpes vulpes). Wildl. Res. 36, 436-446. https://doi.org/10.1071/WR08069 (2009).

77. Karp, D. Detecting small and cryptic animals by combining thermography and a wildlife detection dog. Sci. Rep. 10, 5220. https:// doi.org/10.1038/s41598-020-61594-y (2020).

\section{Acknowledgements}

We would like to thank Rob Dekker, Martijn Spierenburg, Joop Coolen, Arjan Gittenberger, Niels Schrieken and Jørn Ari for their help during field work. We also thank Torkild Bakken (NTNU University Museum) and the team of Gulen Dive Center (Christian Skauge, Ørjan Sandnes, Monica Bakkeli and Guido Schmitz) for their generous help during fieldwork in Norway. Gregory Brown is thanked for permission to use original figures from the Thompson \& Brown ${ }^{40}$ monograph (written permission is included into submission). Ben Rowson (National Museum of Wales) and Andreia Salvador (NHM London) are thanked for the information on Alder and Hancock materials. Electron Microscopy Laboratory, Moscow State University is gratefully acknowledged for support with 
the scanning electron microscopy. This work was supported by a research project of MSU Zoological Museum (18-1-21 No. 121032300105-0). The work of TK was conducted under the IDB RAS Government basic research program in 2021 No. 0088-2021-0008. The research was done using equipment of the Core Centrum of IDB RAS. The authors would like to thank the Department for Communities (NI) and the Department of Agriculture, Environment and Rural Affairs (NI) for funding the Open Access publication of this paper.

\section{Author contributions}

The manuscript was written by A.M. and T.K. T.K., A.M., and F.D. performed preliminary analyses. T.K. performed final molecular phylogenetic and statistical analyses. F.D., B.P., T.K. and A.M. obtained data in the field. A.M. performed scanning electron microscopic study and obtained respective data. T.K. and AM prepared the figures. A.M., T.K., F.D., and B.P. read, checked and approved the submitted version of the manuscript.

\section{Competing interests}

The authors declare no competing interests.

\section{Additional information}

Supplementary Information The online version contains supplementary material available at https:/doi.org/ 10.1038/s41598-021-94863-5.

Correspondence and requests for materials should be addressed to A.V.M.

Reprints and permissions information is available at www.nature.com/reprints.

Publisher's note Springer Nature remains neutral with regard to jurisdictional claims in published maps and institutional affiliations.

(c) (i) Open Access This article is licensed under a Creative Commons Attribution 4.0 International License, which permits use, sharing, adaptation, distribution and reproduction in any medium or format, as long as you give appropriate credit to the original author(s) and the source, provide a link to the Creative Commons licence, and indicate if changes were made. The images or other third party material in this article are included in the article's Creative Commons licence, unless indicated otherwise in a credit line to the material. If material is not included in the article's Creative Commons licence and your intended use is not permitted by statutory regulation or exceeds the permitted use, you will need to obtain permission directly from the copyright holder. To view a copy of this licence, visit http://creativecommons.org/licenses/by/4.0/.

(C) The Author(s) 2021 